\title{
Cooperative Therapeutic Action of Retinoic Acid Receptor and Retinoid X Receptor Agonists in a Mouse Model of Alzheimer's Disease
}

\author{
Kohichi Kawahara ${ }^{\mathrm{a}, \mathrm{b}, 1, *}$, Michita Suenobu $^{\mathrm{a}, \mathrm{b}, 1}$, Hideyuki Ohtsuka ${ }^{\mathrm{a}, \mathrm{b}}$, Akihiko Kuniyasu ${ }^{\mathrm{a}, \mathrm{b}}$, \\ Yukihiko Sugimoto $^{\mathrm{b}}$, Madoka Nakagomi ${ }^{\mathrm{c}}$, Hiroshi Fukasawa ${ }^{\mathrm{c}}$, Koichi Shudo ${ }^{\mathrm{c}}$ and Hitoshi Nakayama ${ }^{\mathrm{a}, *}$ \\ ${ }^{a}$ Department of Molecular Cell Function, Faculty of Life Sciences, Kumamoto University, Kumamoto, Japan \\ ${ }^{\mathrm{b}}$ Department of Pharmaceutical Biochemistry, Faculty of Life Sciences, Kumamoto University, Kumamoto, Japan \\ ${ }^{\mathrm{c}}$ Research Foundation ITSUU Laboratory, Setagaya-ku, Tokyo, Japan
}

Handling Associate Editor: Shun Shimohama

Accepted 14 April 2014

\begin{abstract}
Alzheimer's disease (AD) is a neurodegenerative process involving amyloid- $\beta(A \beta)$ peptide deposition, neuroinflammation, and progressive memory loss. Here, we evaluated whether oral administration of retinoic acid receptor (RAR) $\alpha, \beta$ agonist Am80 (tamibarotene) or specific retinoid X receptor (RXR) pan agonist HX630 or their combination could improve deficits in an AD model, 8.5-month-old amyloid- $\beta$ protein precursor 23 (AßPP23) mice. Co-administration of Am80 $(0.5 \mathrm{mg} / \mathrm{kg})$ and $\mathrm{HX} 630$ $(5 \mathrm{mg} / \mathrm{kg})$ for 17 days significantly improved memory deficits (Morris water maze) in A $\beta P P 23$ mice, whereas administration of either agent alone produced no effect. Only co-administration significantly reduced the level of insoluble $A \beta$ peptide in the brain. These results thus indicate that effective memory improvement via reduction of insoluble $A \beta$ peptide in 8.5-month-old A $\beta P P 23$ mice requires co-activation of RAR $\alpha, \beta$ and RXRs. RAR $\alpha$-positive microglia accumulated A $\beta$ plaques in the A $\beta P P 23$ mice. Rat primary microglia co-treated with Am80/HX630 showed increased degradation activity towards ${ }^{125}$ I-labeled oligomeric $\mathrm{A} \beta_{1-42}$ peptide in an insulin-degrading enzyme (IDE)-dependent manner. The co-administration increased mRNA for IDE and membrane-associated IDE protein in vivo, suggesting that IDE contributes to A $\beta$ clearance in Am80/HX630-treated A $\beta P P 23$ mice. Am80/HX630 also increased IL-4R $\alpha$ expression in microglial MG5 cells. The improvement in memory of Am80/HX630treated A $\beta P P 23$ mice was correlated with the levels and signaling of hippocampal interleukin-4 (IL-4). Therefore, Am80/HX630 may promote differentiation of IL-4-responsive M2-like microglia and increase their activity for clearance of oligomeric A $\beta$ peptides by restoring impaired IL-4 signaling in A $\beta P P 23$ mice. Combination treatment with RAR and RXR agonists may be an effective approach for AD therapy.
\end{abstract}

Keywords: Alzheimer's disease, Am80, amyloid- $\beta$ peptides, HX630, interleukin-4, memory improvement

\footnotetext{
${ }^{1}$ These authors contributed equally to this work.

${ }^{*}$ Correspondence to: Drs. Hitoshi Nakayama and Kohichi Kawahara, Department of Molecular Cell Function, Faculty of Life Sciences, Kumamoto University, Kumamoto 862-0973, Japan. Tel.: +81 96371 4358; Fax: +81 96372 7182; E-mails: jin@ gpo.kumamoto-u.ac.jp; kkawa@gpo.kumamoto-u.ac.jp (Kohichi Kawahara).
}

\section{INTRODUCTION}

Alzheimer's disease (AD) is a serious neurodegenerative disorder with no effective treatment. Its onset and progression correlate with neuroinflammatory processes [1], and inflammatory microglia are associated with AD-like pathology in a transgenic mouse model $[2,3]$. 
Retinoids are analogues of vitamin A-derived all-trans retinoic acid (ATRA), and are specific modulators of many cellular functions, including immunity [4]. Retinoic acid (RA) exerts its biological actions by binding to its cognate nuclear receptors, retinoic acid receptors (RARs), which heterodimerize with retinoid $\mathrm{X}$ receptors (RXRs) to regulate transcription of target genes. Each of them has three subtypes: $\operatorname{RAR} \alpha, \beta, \gamma$ and $\operatorname{RXR} \alpha, \beta, \gamma$.

Vitamin $A$ deprivation results in $A \beta$ accumulation in rats [5]. RA increases gene transcription of a disintegrin and metalloprotease, family 10 (ADAM10) [6-8] and increases its $\alpha$-secretase activity, which cleaves a specific site of amyloid- $\beta$ protein precursor (A $\beta P P$ ). This cleavage inhibits $A \beta$ generation and leads to release of the soluble neuroprotective protein $\mathrm{SA} \beta \mathrm{PP} \alpha$ [9-11]. Clinical evidence has indicated that late-onset AD brains have a defect in retinoid transport function [12]. Therefore, RA or synthetic retinoids may be candidates for treatment of $\mathrm{AD}[5,13-17]$. We previously demonstrated that oral administration of Am80 (0.5 mg/kg/d, for 14 weeks) reduced levels of Tris-buffered saline (TBS)-insoluble $A \beta_{42}$ in brains of 5-month-old AßPP23 mice, an AD model [15]. However, that study did not detect behavioral benefits of this treatment. Recently, Cramer et al. [16] reported that the RXR-selective agonist bexarotene enhanced apolipoprotein E-dependent $A \beta$ clearance from the brain and improved behavioral deficits in A $\beta P P / P S 1$ mice. However, there are conflicting data regarding the therapeutic effect of bexarotene on A $\beta P P$ mice [18-22]. Furthermore, it remains unclear whether coactivation of RARs with RXRs is required to improve AD pathology and memory deficits.

Retinoids modify T helper (Th) types 1 and 2 cells and regulatory T-cell-associated immune responses in rodents and humans [23]. They also suppress Th1 development and enhance development of nä̈ve CD4 T cells to interleukin (IL)-4-producing Th2 cells [24]. IL-4 plays an essential role in higher functions, such as memory and learning, of normal brain [25]. For example, IL-4-deficient mice show cognitive impairment in spatial learning tasks [26]. However, it remains unclear whether retinoids affect $\mathrm{AD}$-associated neuroinflammatory processes in vivo.

In this study, we investigated whether a combination of RAR $\alpha, \beta$ agonist Am80 [27, 28] and RXR pan agonist HX630 [29, 30] would produce any memory improvement in A $\beta P P 23$ mice. We also determined the brain levels of TBS-soluble and TBS-insoluble $A \beta$ and several molecules related to $A \beta$ metabolism (including degradation and phagocytotic clearance of $A \beta$ in vivo and in vitro) before and after the retinoid treatments. We also examined the effects of Am80 and HX630 on neuroinflammatory processes in A $\beta P P 23$ mice.

\section{MATERIALS AND METHODS}

\section{Compounds}

Tamibarotene (also known as Am80) and HX630 were prepared as previously described [31, 32]. GW9662 was obtained from Cayman Chemical (Ann Arbor, MI, USA). These compounds were dissolved in DMSO for in vitro study (stock solution: $10 \mathrm{mM}$ ).

\section{Animals}

Hemizygous A $\beta P P 23$ mice, which overexpress human-type A $\beta P P$ carrying the double mutation K670 N/M671 L, were produced and bred as previously described [33]. Only male mice were analyzed. Wistar rats were obtained from Kyudo Co., Ltd. (Kumamoto, Japan). Animals were housed in standard mouse cages under standard laboratory conditions: food and water available ad libitum, constant room temperature and humidity, and a $12 \mathrm{~h}$ light $/ 12 \mathrm{~h}$ dark cycle (light on from $08: 00$ to 20:00). These animal experiments were conducted according to the guidelines of the Ministry of Education, Culture, Sports, Science, and Technology of Japan, and were approved by the Institutional Animal Care and Use Committee of Kumamoto University (\#B25-133).

\section{Cell culture}

Primary microglia (type 1) were harvested from primary mixed glial cell cultures prepared from neonatal Wistar rat pups, as previously reported [34]. Mouse microglial cell line MG5 and mouse glial cell line A1 were maintained as previously described [35]. Mouse neuroblastoma cell line N1E-115 and Neuro 2a (American Type Culture Collection, Manassas, VA, USA) were maintained in Dulbecco's modified Eagle's medium (DMEM) supplemented with $10 \%$ fetal bovine serum (FBS), $20 \mathrm{U} / \mathrm{ml}$ penicillin (Invitrogen, Gaithersburg, MD, USA), and $20 \mu \mathrm{g} / \mathrm{ml}$ streptomycin (Invitrogen). Primary rat microglia were treated with Am80 (5 $\mathrm{MM})$ and/or HX630 (5 $\mu \mathrm{M})$ in the presence and absence of GW9662 (10 $\mu \mathrm{M})$ for $48 \mathrm{~h}$ in Eagle's MEM supplemented with $10 \%$ FBS and $0.2 \%$ glucose. MG5 cells and A1 cells were treated with Am80 $(5 \mu \mathrm{M})$ and/or HX630 $(5 \mu \mathrm{M})$ for $48 \mathrm{~h}$ in DMEM containing $10 \%$ FBS. 
N1E-115 cells were treated with Am80 $(5 \mu \mathrm{M})$ and/or HX630 $(5 \mu \mathrm{M})$ for 5 days in DMEM containing $2 \%$ FBS.

Since the effective concentration of Am80 in vivo has not been determined, we considered that a relatively high concentration of Am80 should be used in the in vitro study in order to ensure adequate stimulation. When we investigated RARE-luciferase activity in Neuro2a cells, Am80 in the concentration range of $0.2-5 \mu \mathrm{M}$ hardly altered the RARE activity (Supplementary Figure 1). Moreover, the combination of HX630 $(5 \mu \mathrm{M})$ with Am80 in the range of $0.2-5 \mu \mathrm{M}$ also had little effect. Therefore, the concentrations of Am80 and HX630 were both set at $5 \mu \mathrm{M}$ for the in vitro study.

\section{Cell assays}

${ }^{125}$ I-Labeled oligomeric $A \beta_{1-42}$ (o-A $\beta_{1-42}$ ) was prepared as described [34]. Cells were cultured in 24well plates for $48 \mathrm{~h}$ in Eagle's MEM supplemented with $10 \%$ FBS in the presence or absence of Am80 $(5 \mu \mathrm{M})$ and HX630 $(5 \mu \mathrm{M})$. After the 48-h treatment, the cells were washed twice with labeling medium (DMEM containing $3 \% \mathrm{BSA}$ ) and then incubated with ${ }^{125} \mathrm{I}$ labeled o- $A \beta_{1-42}$ for $6 \mathrm{~h}$ at $37^{\circ} \mathrm{C}$. Following the 6-h incubation, medium was removed from each well, and soluble radioactivity in TCA (degraded and extracellularly released peptide fragments) was determined as an index of $A \beta$ degradation in the medium as described previously [34]. The $A \beta$ degradation activity may thus include both receptor-mediated phagocytic activity and extracellular protease-mediated degradation. Cells were washed three times with PBS, then lysed with $0.4 \mathrm{ml}$ of $0.1 \mathrm{M} \mathrm{NaOH}$ for $30 \mathrm{~min}$ at $37^{\circ} \mathrm{C}$, and cell-associated (including cell-incorporated) radioactivity and cell proteins were determined with an autogamma counter and the BCA Protein Assay Reagent (Pierce), respectively. We could not determine the activity of IDE-dependent degradation in this medium, because the incubation medium was replaced with labeling medium prior to incubation with ${ }^{125} \mathrm{I}-\mathrm{o}-\mathrm{A} \beta$.

\section{Drug administration}

A $\beta P P 23$ mice begin forming amyloid deposits when they are 6 months old, but memory deficits in the MWM test appear quite early (before 3 months of age) [36]. Here, we used 8.5-month-old male А $\beta P P 23$ mice and their wild-type (WT) littermates (C57BL/6J). We used stratified random sampling to divide mice (four to six per cage) into four groups to equalize the mean body weight of the study groups: mice given $0.5 \mathrm{mg} / \mathrm{kg} / \mathrm{d}$ Am80, those given $5 \mathrm{mg} / \mathrm{kg} / \mathrm{d}$ HX630, those given the mixture of $0.5 \mathrm{mg} / \mathrm{kg} / \mathrm{d} \mathrm{Am} 80$ and $5 \mathrm{mg} / \mathrm{kg} / \mathrm{d}$ HX630, and those given the vehicle. Am80 and HX630 were suspended in $0.5 \%(\mathrm{w} / \mathrm{v})$ carboxymethylcellulose solution and were orally administered to mice at $0.5 \mathrm{mg} / \mathrm{kg}$ (Am80) or $5 \mathrm{mg} / \mathrm{kg}$ (HX630) for 17 consecutive days (once daily at 18:00). Control animals received the same volume of $0.5 \%(\mathrm{w} / \mathrm{v})$ carboxymethylcellulose solution orally, without the other compounds. We set the $0.5 \mathrm{mg} / \mathrm{kg} / \mathrm{d}$ dose for Am80 on the basis that this had been found effective in other in vivo studies, such as those by Kawahara et al. [15] and Ishido and Shudo [37]. Higher doses of Am80 (3 mg/kg/d and $6 \mathrm{mg} / \mathrm{kg} / \mathrm{d})$ were also orally administered to mice for 17 consecutive days. Animals were weighed once a week. Mice were subjected to behavioral testing on days 15-18 of the first oral administration of the compounds (at $19: 00-23: 00$ ). On days $15-17$ (not day 18 ), animals received the compounds at 24:00, after behavioral testing. On the last day of behavioral testing (day 18), animals received no compounds and tissues were sampled.

\section{Morris water maze (MWM) test}

The MWM test was performed as described previously $[15,38]$. For this test, administered during the $12 \mathrm{~h}$ dark period, a circular, $150-\mathrm{cm}$-diameter pool $(40 \mathrm{~cm}$ high) was filled with water maintained at $23.0 \pm 1^{\circ} \mathrm{C}$. A $12-\mathrm{cm}$-diameter round platform was placed in one quadrant and was kept $1 \mathrm{~cm}$ below the water surface. During acquisition training, mice completed three to five trials daily for 4 consecutive days: day $1: 3$ trials, day $2: 3$ trials, day $3: 5$ trials, and day $4: 4$ trials. The trials began at three different positions in semirandom order, and intertrial intervals were $20 \mathrm{~min}$. A mouse that could not find the platform in $120 \mathrm{~s}$ was carefully guided to the platform and was allowed to stay there for $20 \mathrm{~s}$. A probe trial followed the acquisition phase: the platform was removed from the maze, and mice were permitted to swim freely for $100 \mathrm{~s}$. During both acquisition and probe trials, the routes of the mice were recorded by means of a computerized video tracking system (CompACT VAS; Muromachi Kikai Co. Ltd., Tokyo, Japan). Training trials measured the time it took for a mouse to find the escape platform. Probe trials determined the percent time spent in each quadrant of the maze. The number of times that a mouse crossed over the training annulus (diameter of $22 \mathrm{~cm}$ ), which was 3.1 times 
the size of the target platform, was also used to analyze performance in the probe trial. In this study, the probe trial was administered at $2 \mathrm{~h}$ after the last training trial. Spatial memory retention of the platform position is considered to reflect short-term memory [39].

\section{Animal tissue sampling}

After the behavior analysis (at $2 \mathrm{~h}$ after the probe trial), mice were anesthetized with an injection of Somnopentil $(50 \mathrm{mg} / \mathrm{kg}$, given intraperitoneally; Kyoritsu Seiyaku, Tokyo, Japan), after which they were perfused transcardially with $30 \mathrm{ml}$ of PBS. Brains were rapidly removed and divided into hemispheres. One hemisphere was snap-frozen in liquid nitrogen for protein analysis. The other hemisphere was snapfrozen in liquid nitrogen for total RNA assay. In some experiments, a hemisphere was divided under a stereomicroscope into four sections: cerebral cortex, hippocampus, cerebellum, and other regions, each of which was snap-frozen in liquid nitrogen and stored at $-80^{\circ} \mathrm{C}$ until use. The number $(n)$ of mice used for experiments is shown in each figure.

\section{Immunoblot analysis}

Rat primary microglia and mouse microglial MG5 cells $\left(5 \times 10^{6}\right.$ cells per 100 -mm dish $)$ were homogenized in RIPA buffer [ $10 \mathrm{mM}$ Hepes- $\mathrm{NaOH}$ (pH 7.4) containing $150 \mathrm{mM} \mathrm{NaCl}, 1 \mathrm{mM}$ EDTA, $1 \%$ Triton X$100,0.5 \%$ sodium deoxycholate, $0.1 \%$ SDS, $1 \mathrm{mM}$ PMSF, $1 \mathrm{mg} / \mathrm{ml}$ leupeptin, $1 \mathrm{mg} / \mathrm{ml}$ pepstatin A, and $10 \mathrm{mg} / \mathrm{ml}$ soybean trypsin inhibitor]. After centrifugation of samples, supernatants were separated by SDS-PAGE and proteins were electrotransferred to nitrocellulose membranes. The cerebral hemispheres and hippocampus were homogenized in 3 volumes $(\mathrm{w} / \mathrm{v})$ and 10 volumes (w/v), respectively, of $50 \mathrm{mM}$ Tris- $\mathrm{HCl}$ buffer (pH 7.6) containing $150 \mathrm{mM} \mathrm{NaCl}$, $1 \mathrm{mM}$ PMSF, $1 \mathrm{mg} / \mathrm{ml}$ leupeptin, $1 \mathrm{mg} / \mathrm{ml}$ pepstatin $\mathrm{A}$, and $10 \mathrm{mg} / \mathrm{ml}$ soybean trypsin inhibitor. Triton X100 -solubilized membrane fractions of the cerebral hemispheres were prepared as described previously [40]. Aliquots of homogenates and membrane fractions were saved for determination of protein, and, after addition of $25 \mathrm{mM}$ DTT, samples were incubated at $60^{\circ} \mathrm{C}$ for $10 \mathrm{~min}$. The samples $(40 \mu \mathrm{g}$ homogenate or $5.0 \mu \mathrm{g}$ membrane fraction) were then subjected to SDS-PAGE, and proteins were electrotransferred to nitrocellulose membranes. These membranes were incubated with Tris-buffered saline (TBS) (pH 7.4) containing $2 \%$ dehydrated skimmed milk to block nonspecific protein binding. Membranes were then incubated with antibodies to CD36 (BAF2519, 1:500 dilution; R\&D Systems), NEP (H-321, $1: 100$ dilution; Santa Cruz Biotechnology, Santa Cruz, CA, USA), IDE (PC730, 1:1000 dilution; Calbiochem, Darmstadt, Germany; 9B12, 1 : 1000 dilution; Abcam, Cambridge, UK), IL-4 receptor $\alpha$ chain (IL-4R $\alpha$ ) (S-20, 1:200 dilution; Santa Cruz Biotechnology), $\mathrm{A} \beta_{1-17}$ (6E10, 1:500 dilution; Chemicon International, Temecula, CA, USA), scavenger receptor class AI/AII (SRA) (SRA-E5, 1:1000 dilution; a gift from Prof. M. Takeya at Kumamoto University, Kumamoto, Japan), or $\beta$-actin (AC15, $1: 5000$ dilution; Sigma), followed by secondary antibodies: horseradish peroxidase-linked antibodies against rabbit, goat, or mouse Ig (each diluted $1: 1000$ ). Bound horseradish peroxidase-labeled antibodies were then detected via chemiluminescence (an ECL kit; Pierce, Rockford, IL, USA). Protein concentrations were determined with the BCA Protein Assay Reagent (Pierce) and Bradford Protein Assay Reagent (Pierce).

\section{Immunohistochemistry}

Mice were anesthetized with pentobarbital, and 4\% PFA in PBS was perfused through the left cardiac ventricle. Brains were removed and embedded in paraffin, before being cut into $4 \mu \mathrm{m}$ thick sections, which were then deparaffinized and incubated with $0.01 \%$ (w/v) 1-fluoro-2,5-bis(3-carboxy4-hydroxystyryl)benzene (FSB, a reagent for amyloid staining; Dojindo, Kumamoto, Japan) for $30 \mathrm{~min}$. After washing with $50 \%$ ethanol, the sections were autoclaved (at $120^{\circ} \mathrm{C}$ ) in $10 \mathrm{mM}$ citrate buffer $(\mathrm{pH}=6.0)$ for $5 \mathrm{~min}$, and washed in PBS. For $\mathrm{A} \beta$ staining (6E10), sections were immersed in $70 \%$ formic acid for $10 \mathrm{~min}$. The sections were then incubated with primary antibodies to RAR $\alpha$ (rabbit IgG, C-20, $1: 100$ dilution; Santa Cruz Biotechnology), RAR $\beta$ (rabbit IgG, C-19, $1: 100$ dilution; Santa Cruz Biotechnology), $\mathrm{A} \beta_{1-17}$ (mouse IgG, 6E10, 1:500 dilution; Chemicon International, Temecula, CA, USA), Iba1 (rat serum, 1:500 dilution; generated against a synthetic peptide corresponding to a specific sequence of mouse Iba1: CNKEHKRPTGPPAKKAISELP (near the C-terminus)), or GFAP (chicken IgY, GTX85454, $1: 200$ dilution; GeneTex), followed by the corresponding Alexa Fluor 488- or 594-labeled secondary antibodies (1:300 dilution; Molecular Probes and Abcam). For immunohistochemistry with anti-Iba1 antibody, we used a tyramide signal amplification 
system (Molecular Probes) according to the manufacturer's recommendations. Specimens were mounted with VECTASHIELD mounting medium (Vector) and were examined with a confocal laser-scanning microscope (FluoView; Olympus).

For immunohistochemical staining with IL-4R $\alpha$, the avidin-biotin peroxidase technique was used. Mice were anesthetized with pentobarbital, and 4\% PFA in PBS was perfused through the left cardiac ventricle. Brains were removed and cryoprotected in sucrose. Frozen sections (10- $\mu \mathrm{m}$ thick) were cut with a cryostat and thaw-mounted on gelatin-coated slides. The coronal sections were immersed in $10 \mathrm{mM}$ citrate buffer $(\mathrm{pH}=6.0)$ and were autoclaved (at $80^{\circ} \mathrm{C}$ ) for $5 \mathrm{~min}$. Endogenous peroxidase was blocked by treatment with $1 \% \mathrm{H}_{2} \mathrm{O}_{2}$ in methanol for $15 \mathrm{~min}$, followed by overnight incubation at $4{ }^{\circ} \mathrm{C}$ with rabbit anti-IL-4R $\alpha$ antibody (S-20, $1: 100$ dilution; Santa Cruz Biotechnology). Rabbit IgG from non-immune serum was used as a negative control. Excess antibody was washed out with PBS, and the sections were incubated for $1 \mathrm{~h}$ with the corresponding biotinylated secondary antibody ( $1: 200$ dilution, Chemicon International). The sections were then incubated for $30 \mathrm{~min}$ at room temperature with avidin-peroxidase complex (Vector). Peroxidase was visualized by incubation with diaminobenzidine solution with nickel enhancement.

\section{ELISA}

The TBS-soluble (TBS-extractable) fraction and the TBS-insoluble (but guanidine $\mathrm{HCl}$-extractable) fraction from the cerebral hemispheres or hippocampus were prepared as described previously $[15,41]$. The amounts of $A \beta_{40}$ and $A \beta_{42}$ in each fraction were determined by using sandwich ELISAs (294-64701 and 290-62601 (Wako), respectively), according to the manufacturer's instructions. The amounts of tumor necrosis factor- $\alpha$ (TNF- $\alpha$ ) and IL- 4 in the TBS-soluble fractions of cerebral cortex and hippocampus were analyzed by means of sandwich ELISAs KMC3012 (Invitrogen) and ELM-IL-4-001 (RayBiotech, Inc., Norcross, GA, USA), respectively, according to the manufacturer's instructions. Protein concentrations were determined with the Bradford Protein Assay Reagent (Thermo Fisher Scientific Inc., Rockford, IL, USA), with BSA as the standard.

\section{RT-PCR Analysis}

Total RNA from the cerebral hemispheres, hippocampus, or MG5 cells was prepared by guanidinium thiocyanate-phenol-chloroform extraction [42]. Then, $1.0 \mu \mathrm{g}$ of total RNA was converted to cDNA with SuperScript III Reverse Transcriptase (Invitrogen) and nucleotide random primer (Invitrogen). Quantitative real-time PCRs were carried out by using the LightCycler 1.5 system (Roche, Mannheim, Germany) with the FastStart DNA Master SYBR Green I LightCycler kit (Roche). The primers used were as follows: for Ide: sense primer, $5^{\prime}$-CGGCCAT CCAGAGAATAGAA- $3^{\prime}$ and antisense primer, $5^{\prime}$-TTT GGAGGGTCTGACAGTGA-3'; for Il4r ${ }^{\prime}$ : sense primer, 5'-CCTCACACTCCACACCAATG-3' and antisense primer, 5'-CCTGGGTTCCTTGTAGGT CA-3'; for Tnf receptor (Tnfr)1: sense primer, 5'ACGGCTTCCCAGAATTACCT- ${ }^{\prime}$ and antisense primer, 5'-TCAGCTTGGCAAGGAGAGAT-3'; for $T n$ fr2: sense primer, 5'-TACCAAGGGTGGCATCTC TC-3' and antisense primer, 5'-AGGGCTTCTT TTTCCTCTGC- $3^{\prime}$; for $R A R \alpha$ (rar $\left.\alpha\right)$ : sense primer, $5^{\prime}$-TTCTTTCCCCCTATGCTGGGT-3' and antisense primer, 5'-GGGAGGGCTGGGTACTATCTC-3'; for $R A R \beta$ ( $\operatorname{rar} \beta)$ : sense primer, 5'-CTGCTCAATCCAT CGAGACAC- $3^{\prime}$ and antisense primer, $5^{\prime}$-CTTG TCCTGGCAAACGAAGC-3'; for tissue-plasminogen activator $(t P A)$ : sense primer, $5^{\prime}$-ATGAGGCATC GTCTCCATTC- $3^{\prime}$ and antisense primer, $5^{\prime}$-ACAGA TGCTGTGAGGTGCAG- ${ }^{\prime}$; and for $\beta$-actin: sense primer, 5'-CTAAGGCCAACCGTGAAAAG-3' and antisense primer, 5'-ACCAGAGGCATACAGGGA CA- $3^{\prime}$. A standard curve for each gene was generated with serial dilutions of the respective PCR product. Expression was normalized against the expression of $\beta$-actin. PCR specificity was confirmed by means of sequencing, gel electrophoresis, and melting curve analysis.

For semi-quantitative RT-PCR analysis, PCRs were carried out with Quick Taq HS DyeMix (DTM101; Toyobo Co. Ltd., Osaka, Japan). The primers used were as follows: for $C d 36$ : sense primer, $5^{\prime}$ AGGTCCTTACACATACAGAGTTCG-3' and antisense primer, 5'-GGACTTGCATGTAGGAAATGT $\mathrm{GGA}^{\prime}$; for membrane metallo-endopeptidase (Mme)/ Nep: sense primer, 5'-CAGCCTCAGCCGAAACTACA-3' and antisense primer, 5'-TTTGTCTCAGCATCCATCCAA-3'; for Ide: sense primer, $5^{\prime}$-CGGCCATCCAGAGAATAGAA- $3^{\prime}$ and antisense primer, $5^{\prime}$-TT TGGAGGGTCTGACAGTGA-3'; for $\beta$-actin: sense primer, 5'-CTAAGGCCAACCGTGAAAAG-3' ${ }^{\prime}$ and antisense primer, 5' - ACCAGAGGCATACAGGGA CA-3'. The primer sets for $C d 36, M m e, I d e$, and $\beta$-actin were expected to give PCR products with sizes of 789, 255, 172, and $104 \mathrm{bp}$, respectively. Semi-quantitative 
PCR consisted of an initial denaturation cycle at $94^{\circ} \mathrm{C}$ for $2 \mathrm{~min}$, followed by 40 cycles for $C d 36,35$ cycles for Mme, 30 cycles for Ide, and 26 cycles for $\beta$-actin. An additional cycle at $72^{\circ} \mathrm{C}$ for $7 \mathrm{~min}$ completed the amplification. Amplified PCR products were separated by $2 \%$ (except for $C d 36,1.5 \%$ ) agarose gel electrophoresis and visualized by staining with ethidium bromide. Densitometric quantification was done with the Image Gauge software program (Fuji Photo Film Co., Tokyo, Japan). Expression was normalized against the expression of $\beta$-actin. PCR specificity was confirmed by means of sequencing and gel electrophoresis.

\section{Transient transfection and reporter gene assay}

MG5 cells $\left(2 \times 10^{6}\right.$ cells in $\left.100 \mu \mathrm{l}\right)$ were transfected by electroporation with $1.0 \mu \mathrm{g}$ of pGL3-RARE-Luc (\#13458; Addgene) or pGL3-Luc vector (Promega) and $0.25 \mu \mathrm{g}$ of Renilla luciferase vector (phRL-TK) (Promega), using the Nucleofector transfection system (program \#D-032; Amaxa) according to the manufacturer's protocol, taken up in the medium, and seeded in 48 -well plates $\left(1.25 \times 10^{5}\right.$ cells/well $)$. For some experiments, cells were transfected with $1.0 \mu \mathrm{g}$ of pGL3-RARE-Luc or pGL3-Luc vector and $0.25 \mu \mathrm{g}$ of phRL-TK in the presence of $0.25 \mu \mathrm{g}$ each of pcDNA3.1-RAR (\#16287; Addgene) and pcDNA3.1RXR (\#8882; Addgene). An empty pcDNA3.1 expression vector was used to maintain equal amounts of DNA for each transfection. Five hours after transfection, the cells were exposed to $\operatorname{Am} 80(5 \mu \mathrm{M})$ and/or HX630 $(5 \mu \mathrm{M})$ in the medium for $24 \mathrm{~h}$. Luciferase activities were determined in cell lysates. Firefly luciferase activity was normalized to that of Renilla luciferase for each well.

Neuro2a cells were seeded in 24 -well plates $\left(2 \times 10^{5}\right.$ cells/well) and transfected with $0.2 \mu \mathrm{g}$ of pGL3RARE-Luc (\#13458; Addgene) or pGL3-Luc vector (Promega) and $0.05 \mu \mathrm{g}$ of Renilla luciferase vector (phRL-TK) (Promega), using Effectene reagent (Qiagen) according to the manufacturer's protocol. Five hours after transfection, cells were exposed to Am80 $(5 \mu \mathrm{M})$ and/or HX630 $(5 \mu \mathrm{M})$ in the medium for $24 \mathrm{~h}$. Luciferase activities were determined in cell lysates. Firefly luciferase activity was normalized to that of Renilla luciferase for each well.

\section{Statistical analysis}

All data were expressed as means \pm SEM. For statistical comparisons of the means between two groups, Student's $t$-test was applied after confirming the equal- ity of group variances. In factorial ANOVA, drug treatment (vehicle, Am80, HX630, or Am80/HX630) was used as a between-subject factor and the training regimen (days or trials) was used as a within-subject (repeated measures) factor. The Bonferroni multiple comparison test was used after two-way ANOVA. For comparisons of three or more groups, Dunnett's multiple comparison test was applied after one-way ANOVA. To determine whether a correlation between variables existed, a scatterplot and Pearson correlation analyses were employed. All statistical analyses were performed with GraphPad Prism (GraphPad Software). Significance was defined as $p$ value $<0.05$.

\section{RESULTS}

Co-administration of Am80 with HX630 reversed deficits in spatial learning and memory in 8.5-month-old $A \beta P P 23$ mice

We orally administered tamibarotene/Am80 (a selective $\operatorname{RAR} \alpha, \beta$ agonist with little or no binding affinity for RAR $\gamma$ and RXRs, $0.5 \mathrm{mg} / \mathrm{kg}$ ), HX630 (a pan RXRs agonist, $5 \mathrm{mg} / \mathrm{kg}$ ), or their combination to 8.5-month-old AßPP23 mice (an AD model) and their WT littermates for 17 days (Fig. 1A). During the experimental period, body weights of the mice in the different groups showed no significant difference (data not shown). Vehicle-treated A $\beta P P 23$ mice showed considerably impaired acquisition of spatial learning (i.e., a longer escape latency) in the MWM test, compared with WT littermates (Fig. 1B; $p<0.001$ by two-way ANOVA). However, co-administration of Am80 with HX630 to A $\beta P P 23$ mice led to a significant improvement in this measure compared with vehicleinjected control A $\beta$ PP23 mice (Fig. 1B; $p<0.001$ by two-way ANOVA). In addition, a post hoc comparison indicated that significant improvement was detected only in the co-administration group, not in groups treated with either agonist alone (Fig. 1B; $p<0.01$ ). In the post hoc comparison among groups, Am80/HX630 co-treatment showed a significant improvement compared with either HX630 treatment (at days 2-4) or Am80 treatment (at days 2 and 3, but not at day 4).

After the acquisition trials, mice underwent probe trials to evaluate retention of memory of the platform location (Fig. 1C). Vehicle-treated A $\beta P P 23$ mice spent a significantly shorter time in the target quadrant $(17.1 \pm 3.6 \%)$ compared with vehicle-treated WT mice $(33.0 \pm 3.2 \%$ ) (Fig. $1 \mathrm{C} ; p<0.01)$. However, Am80/HX630-treated A 3 PP23 mice spent a significantly longer time in the target quadrant $(30.5 \pm 6.1 \%)$ 
A<smiles>CC1(C)CCC(C)(C)c2cc(NC(=O)c3ccc(C(=O)O)cc3)ccc21</smiles>

Tamibarotene/Am80<smiles>CC1(C)CCC(C)(C)c2cc3c(cc21)Sc1ccccc1N=C3c1ccc(C(=O)O)cc1</smiles>

HX630

C

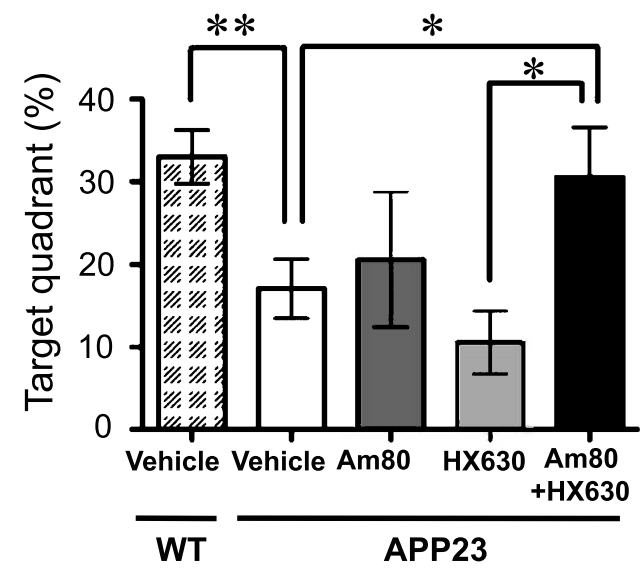

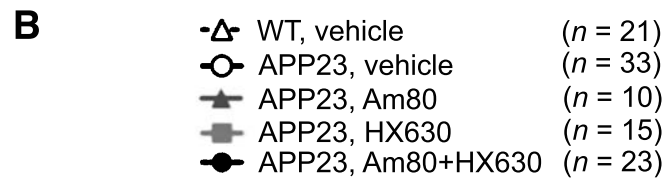

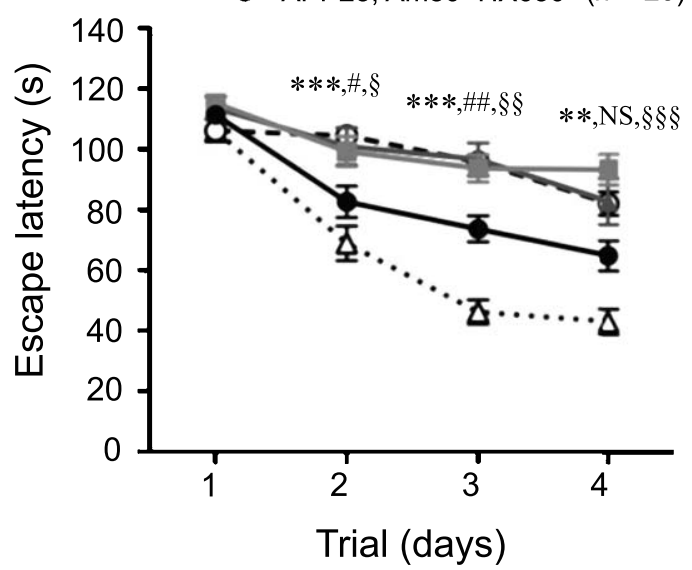

D

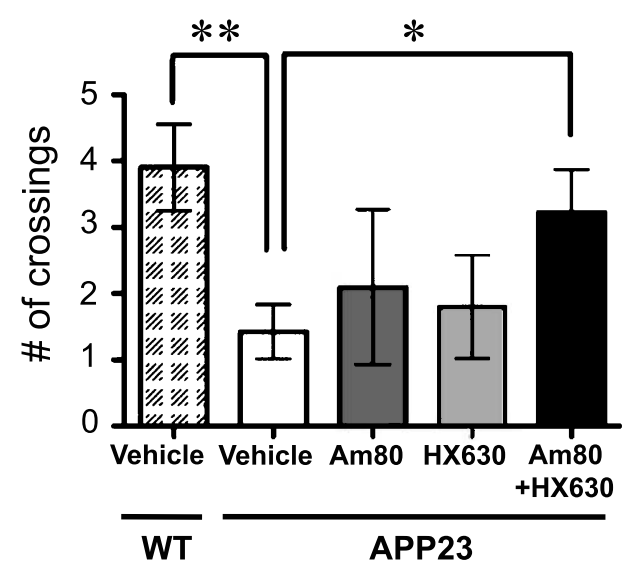

Fig. 1. Co-administration of Am80 with HX630 reversed deficits in spatial learning and memory in 8.5-month-old male A 3 PP23 mice. A) Chemical structure of synthetic retinoids, tamibarotene/Am80, and HX630. B-D) Am80 and/or HX630 were orally administered to mice at $0.5 \mathrm{mg} / \mathrm{kg}$ (Am80) or $5 \mathrm{mg} / \mathrm{kg}$ (HX630) for 17 consecutive days. Spatial learning and memory were evaluated by means of the MWM test from day 15 to day 18 of the first oral administration of the compounds. Error bars represent means \pm SEM $(n=21$ in vehicle-treated WT mice, $n=33$ in vehicle-treated A $\beta P P 23$ mice, $n=10$ in Am80-treated A $\beta P P 23$ mice, $n=15$ in HX630-treated A $\beta P P 23$ mice, $n=23$ in Am80/HX630-treated A $\beta$ PP23 mice). B) For 4 consecutive days, mice learned to swim to a hidden platform. Each point indicates the mean latency to find the escape platform in three to five trials per day \pm SEM for each group. Statistical significance of differences was calculated by using two-way ANOVA followed by the post hoc Bonferroni multiple comparison test. Significant differences with ${ }^{* * *} p<0.001$ (at days 2 and 3 ) and ${ }^{* *} p<0.01$ (at day 4) were detected between Am80/HX630-treated AßPP23 mice and vehicle-treated ones. Differences between Am80/HX630-treated A 3 PP23 mice and Am80-treated ones were observed as ${ }^{\#} p<0.05$ (at day 2), ${ }^{\# \#} p<0.01$ (at day 3), and not significant (NS, at day 4) Significant differences between Am80/HX630-treated AßPP23 mice and HX630-treated ones were detected as ${ }^{2} p<0.05$ (at day 2), $\S_{3} p<0.01$ (at day 3), and $\delta \S \S p<0.001$ (at day 4). No significant difference was observed among the three groups: vehicle-treated, Am80-treated, and HX630-treated AßPP23 mice. C, D) Memory test in the MWM probe trial without the platform. The probe trial was administered at $2 \mathrm{~h}$ after the last training trial (i.e., at day 18 after the start of treatment). Measures included (C) the time (\%) spent searching the target quadrant and (D) the number of crossings over the training annulus $\left(3.1 \times\right.$ the size of the target platform) during a probe trial (a 100 -s session). ${ }^{* *} p<0.01$ and ${ }^{*} p<0.05$ by Student's $t$-test. No significant difference was observed for Am80/HX630 co-treatment relative to the Am80 (C, D) and HX630 treatments (D).

than did vehicle-treated A 3 PP23 mice (Fig. 1C; $p<0.05)$. In addition, Am80/HX630-treated A $\beta$ PP23 mice spent a significantly longer time in the tar- get quadrant than did HX630-treated mice (Fig. 1C; $p<0.05)$. As expected, vehicle-treated A $\beta P P 23$ mice had significantly fewer crossings over the training 
A

Soluble fraction: $A \boldsymbol{\beta}_{40}$

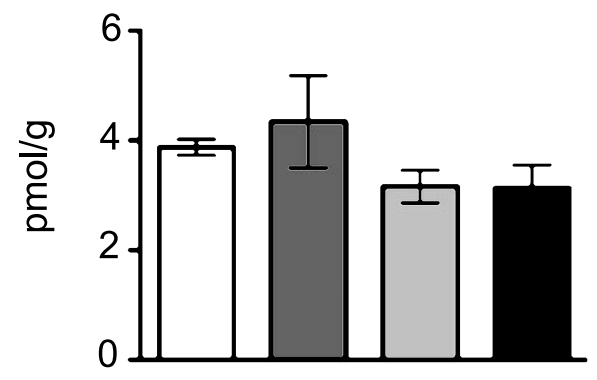

B

Insoluble fraction: $A \beta_{40}$

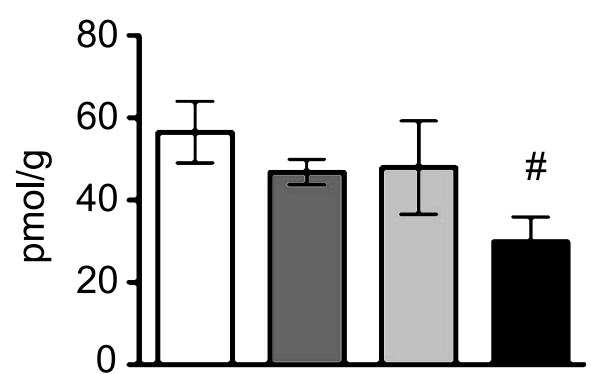

C Soluble fraction: $A \boldsymbol{\beta}_{42}$

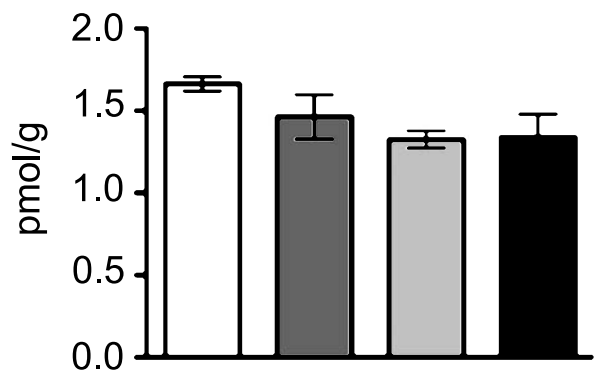

D

Insoluble fraction: $A \beta_{42}$

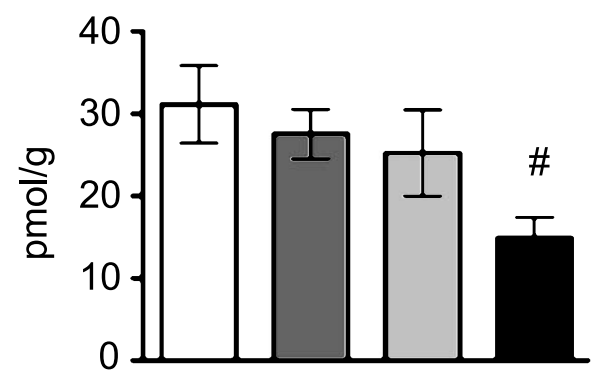

$(n=5)$

$\operatorname{Am} 80+\mathrm{HX} 630(n=6)$

Fig. 2. Co-administration of Am80 $(0.5 \mathrm{mg} / \mathrm{kg} / \mathrm{d})$ with $\mathrm{HX} 630(5 \mathrm{mg} / \mathrm{kg} / \mathrm{d})$ significantly reduced TBS-insoluble $A \beta_{40}$ and $A \beta_{42}$ levels in the brains of male A $\beta P P 23$ mice. After the 4-day behavioral study (i.e., at 18 days after the start of treatment), $A \beta_{40}(A, B)$ and $A \beta_{42}(C, D)$ levels in TBS-soluble (A, C) and TBS-insoluble (B, D) fractions of mouse brains were determined by using sandwich ELISA. Error bars represent means \pm SEM. ${ }^{\#} p<0.05$ by Dunnett's multiple comparison test, relative to the vehicle-treated groups. No significant difference was observed for the Am80/HX630 group compared to the Am80 and HX630 groups (B, D).

annulus $(1.42 \pm 0.41)$ compared with vehicle-treated WT mice $(3.90 \pm 0.65)$ (Fig. $1 \mathrm{D} ; p<0.01)$. After co-administration of Am80 with HX630, however, A $\beta$ PP23 mice had a significantly higher score $(3.22 \pm 0.65)$ than did vehicle-treated $\mathrm{A} \beta \mathrm{PP} 23$ mice (Fig. 1D; $p<0.05$ ). Thus, co-administration of Am80/HX630 rapidly improved memory deficits in middle-aged A $\beta P P 23$ mice.

Co-administration of Am80 with HX630 reduced TBS-insoluble $A \beta_{40}$ and $A \beta_{42}$ levels in $A \beta P P 23$ mouse brains

We used sandwich ELISA to determine and compare the amounts of $A \beta_{40}$ and $A \beta_{42}$ in Tris-buffered saline (TBS)-soluble and -insoluble brain fractions (Fig. 2). Administration of Am80 $(0.5 \mathrm{mg} / \mathrm{kg} / \mathrm{d})$ or HX630 $(5 \mathrm{mg} / \mathrm{kg} / \mathrm{d})$ or their combination for 17 days had no effect on levels of $A \beta_{40}$ and $A \beta_{42}$ in the
TBS-soluble brain fraction of 8.5-month-old A $\beta P P 23$ mice (Fig. 2A, C). In contrast, levels of $A \beta_{40}$ and $\mathrm{A} \beta_{42}$ in TBS-insoluble brain fractions were significantly lower in the Am80/HX630-treated group than in the other three groups (Fig. 2B, D). These results indicate that reduction of insoluble $A \beta$ in brain of Am80/HX630-treated mice was correlated with memory improvement. The A $\beta$ levels in 8.5-month-old WT mice were not determined, because preliminary tests showed they were below the detection limit of the ELISA system (data not shown).

\section{Am80/HX630 increased levels of NEP and IDE proteins in vivo}

Enzymatic degradation of $\mathrm{A} \beta$ peptides and microglia-mediated phagocytosis are involved in $A \beta$ clearance, especially from insoluble fractions [43]. Activated microglia accumulated around amyloid 

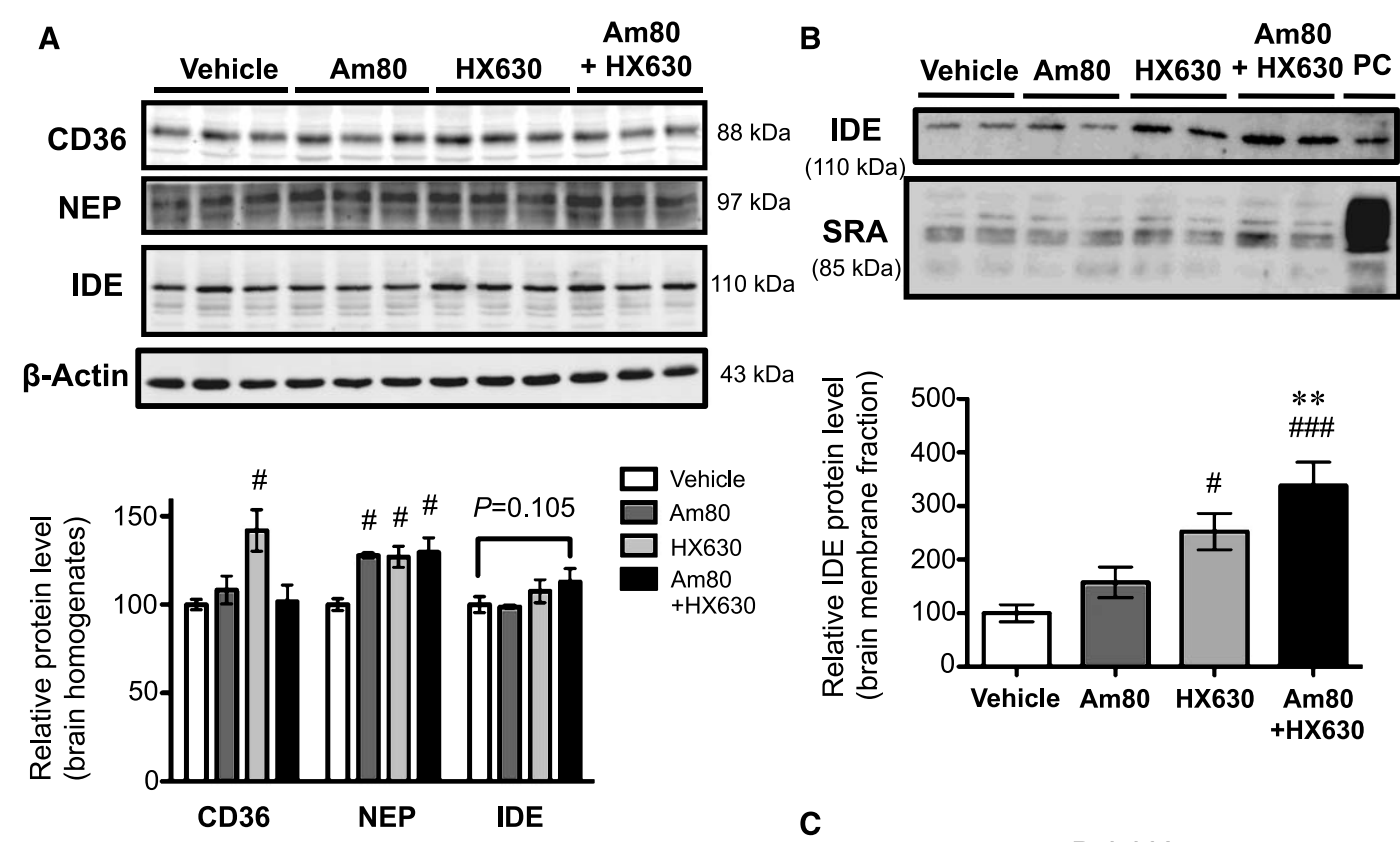

c

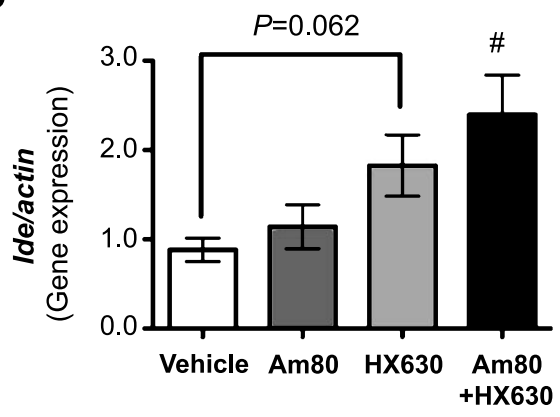

Fig. 3. Am80/HX630 increased NEP and IDE protein levels as well as Ide mRNA level in male A $3 P P 23$ mice. At 18 days after beginning treatment with Am80 (0.5 mg/kg/d) and/or HX630 (5 mg/kg/d), whole-cell extracts (A), homogenates of the membrane-bound fraction (B), and total RNA were prepared from the brains of A $\beta$ PP23 mice (A-C). A, B) Immunoblotting with antibodies to CD36, NEP, IDE, $\beta$-actin, or SRA was used to study the homogenates ( $40 \mu \mathrm{g}$ in A, $5 \mu \mathrm{g}$ in B). Positive controls (PC) in B are the membrane fractions ( $5 \mu \mathrm{g}$ ) from brains of WT mice for IDE, and cell lysates from MG5 microglial cells for SRA. The upper panel in B shows representative immunoblotting results of IDE and SRA in the membrane-bound fraction. Densitometric scanning was used to quantify results. Values were normalized to SRA protein expression, and were expressed relative to the vehicle-treated mice. Error bars represent means \pm SEM, $n=3$ (A) and 5 (B) mice per group. ${ }^{\# \# \#} p<0.001$ and ${ }^{\#} p<0.05$ by Dunnett's multiple comparison test, relative to the vehicle-treated group. ${ }^{* *} p<0.01$ by Dunnett's multiple comparison test, relative to the Am80-treated group. C) The RNA samples $(1.0 \mu \mathrm{g})$ were subjected to quantitative RT-PCR using a specific primer for Ide gene. Values were normalized to $\beta$-actin gene expression. Error bars represent means \pm SEM $(n=3-4)$. ${ }^{*} p<0.05$ by Dunnett's multiple comparison test, relative to the vehicle-treated A $\beta P P 23$ mice. $p=0.062$ by Student's $t$-test for HX630-treated A $\beta P P 23$ mice, relative to the vehicle-treated AßPP23 mice.

plaques (Supplementary Figure 2A-E) [43] and expressed $\mathrm{RAR} \alpha$ in vehicle-treated 8.5-month-old male A $\beta P P 23$ mice (Supplementary Figure 2A-E). Astrocytes also expressed RAR $\alpha$ in the vicinity of amyloid plaque (Supplementary Figure 2F-J). It is noteworthy that $\mathrm{RAR} \alpha$ staining in microglia was almost entirely localized in nuclei, in contrast to the uniformly stained astrocytes, suggesting that RAR $\alpha$ was already activated in microglia. Immunoblot analysis of brain samples revealed that the level of scavenger receptor CD36 protein was increased in
HX630-treated mice, but CD36 was not increased after co-administration of HX630 with Am80 (Fig. 3A). Higher levels of NEP protein were found in Am80-, HX630-, and Am80/HX630-treated AßPP23 mice than in vehicle-treated mice (Fig. 3A). The IDE protein level was indistinguishable among the four groups (Fig. 3A). However, the IDE protein level in the membrane-bound fraction was increased significantly in HX630- and Am80/HX630-treated A $\beta P P 23$ mice compared with vehicle-treated A $\beta P P 23$ mice (Fig. 3B; $p<0.05)$. The Ide mRNA level was also increased 
A
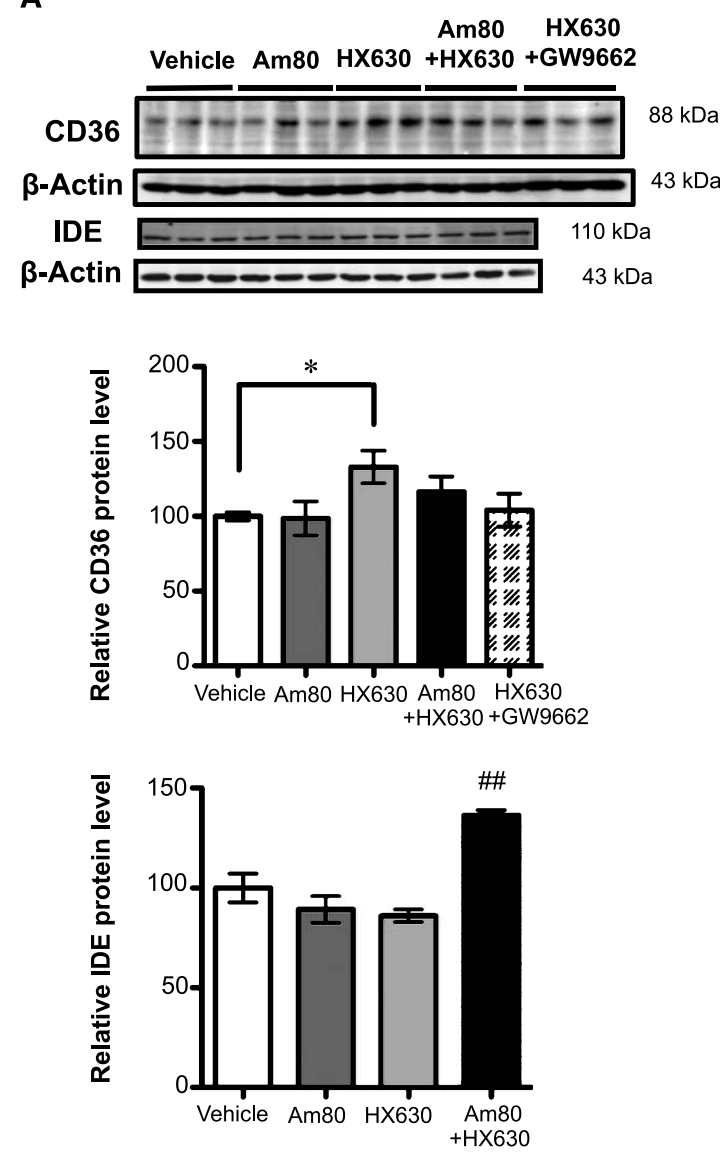

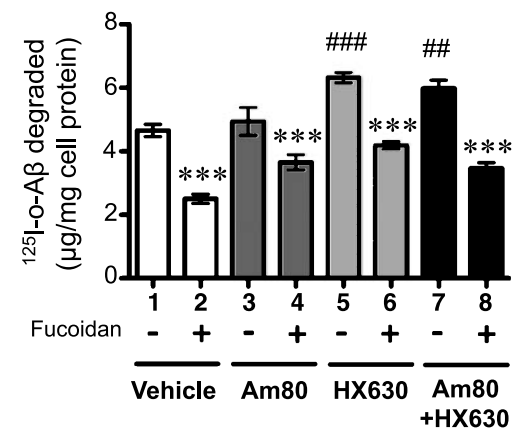

C

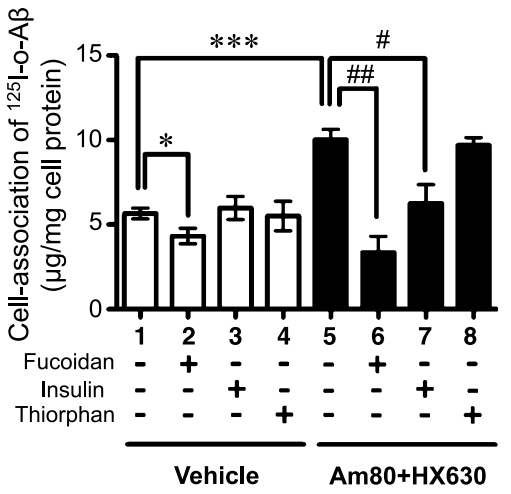

D

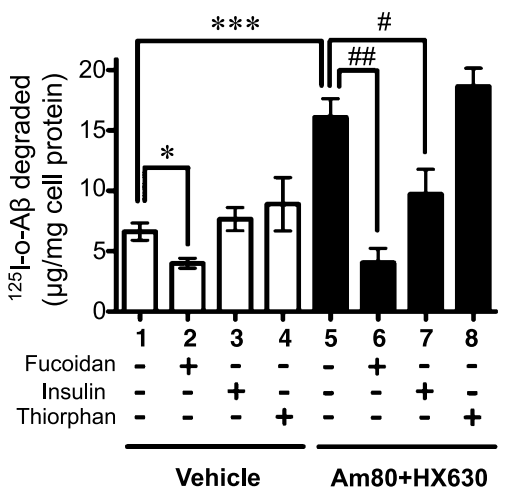

Fig. 4. Clearance of ${ }^{125}$ I-labeled oligomeric $A \beta_{1-42}\left(\mathrm{o}-\mathrm{A} \beta_{1-42}\right)$ by rat primary microglia. A) Rat primary microglia were incubated with $A m 80$ $(5 \mu \mathrm{M})$ and/or HX630 $(5 \mu \mathrm{M})$ for $48 \mathrm{~h}$. Cell proteins $(30 \mu \mathrm{g})$ were subjected to immunoblot analysis with antibodies to CD36, IDE, or $\beta$-actin. Densitometric scanning was used to quantify results. Values were normalized to $\beta$-actin protein expression, and were expressed relative to those of vehicle-treated cells. Error bars represent means $\pm \operatorname{SEM}(n=3) .{ }^{\# \#} p<0.01$ by Dunnett's multiple comparison test, relative to the vehicle-treated cells. B) Cells were cultured for $48 \mathrm{~h}$ with Am80 $(5 \mu \mathrm{M})$ and/or HX630 $(5 \mu \mathrm{M})$ and then incubated for $6 \mathrm{~h}$ with ${ }^{125}$ I-labeled o-A $\beta_{1-42}(1 \mu \mathrm{g} / \mathrm{ml})$ in the presence or absence of fucoidan $\left(100 \mu \mathrm{g} / \mathrm{ml}\right.$, a scavenger receptor inhibitor). The amounts of degradation products of ${ }^{125} \mathrm{I}$-labeled o-A $\beta$ were determined. Error bars represent means \pm SEM, $n=6$. \#\#\# $p<0.001$ and ${ }^{\# \#} p<0.01$ by Dunnett's multiple comparison test, relative to the vehicle-treated cells (column 1). ${ }^{* * *} p<0.001$ by Student's $t$-test, in the presence or absence of fucoidan. C, D) Cells were cultured for $48 \mathrm{~h}$ with Am80 $(5 \mu \mathrm{M})$ and/or HX630 $(5 \mu \mathrm{M})$ and then incubated for $6 \mathrm{~h}$ with ${ }^{125}$ I-labeled o-A $\beta_{1-42}(1 \mu \mathrm{g} / \mathrm{ml})$ in the presence or absence of fucoidan $(100 \mu \mathrm{g} / \mathrm{ml})$, insulin $(100 \mu \mathrm{g} / \mathrm{ml}$, an IDE inhibitor), or thiorphan (30 $\mu \mathrm{M}$, a NEP inhibitor). The amounts of cell-association (C) and degradation products (D) of ${ }^{125}$ I-labeled o-A $\beta$ were determined. Error bars represent means \pm SEM, $n=6$. ${ }^{* * *} p<0.001$ and ${ }^{*} p<0.05$ by Student's $t$-test. $\# p<0.01$ and ${ }^{\#} p<0.05$ for column 5 among columns $5-8$, by Dunnett's multiple comparison test. 
A

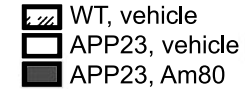

APP23, HX630 APP23, Am80+HX630

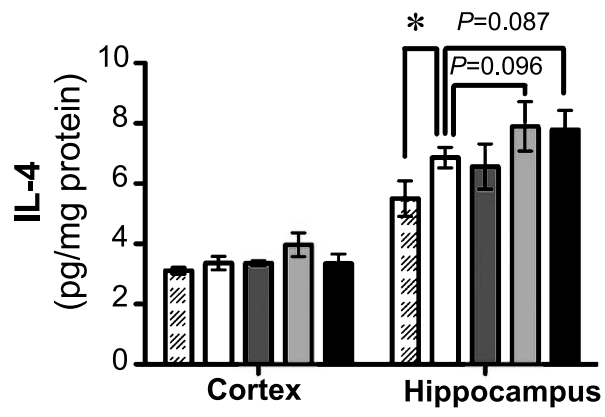

Ba

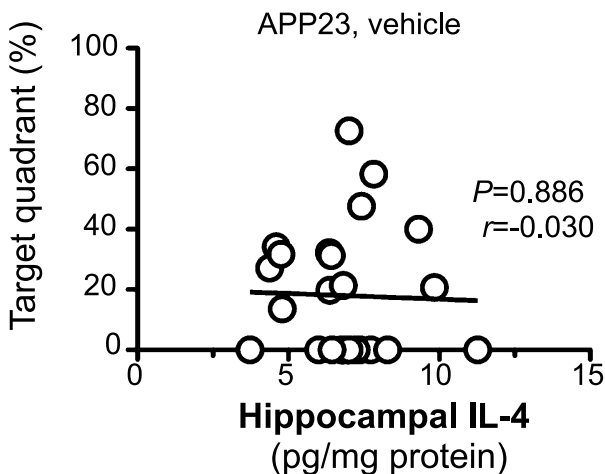

C

\section{Insoluble fraction: $A \beta_{42}$ (Hippocampus)}

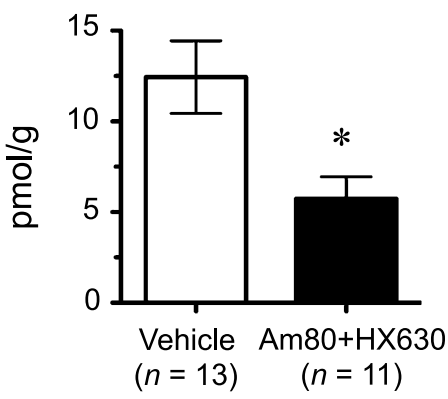

$\mathrm{Bb}$

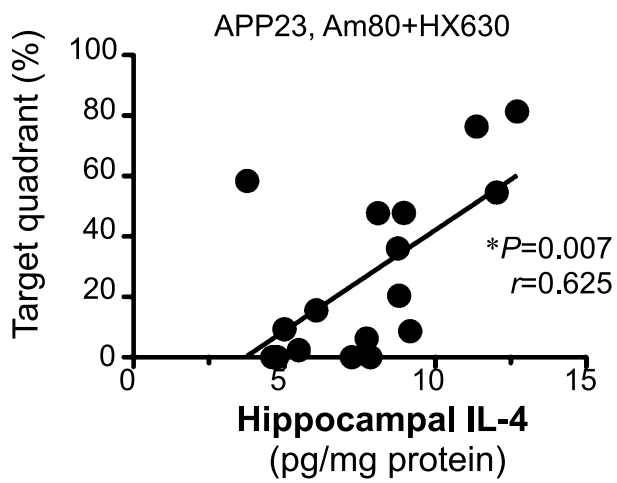

Fig. 5. Am80/HX630-treated male AßPP23 mice showed a significant positive correlation between hippocampal IL-4 levels and performance in the MWM test, but vehicle-treated mice did not. A) At 18 days after beginning treatment with Am80 (0.5 mg/kg/d) and/or HX630 (5 mg/kg/d), levels of IL-4 in TBS-soluble fractions of the cerebral cortex and hippocampus were determined via sandwich ELISA. Error bars represent means $\pm \operatorname{SEM}(n=6$ in vehicle-treated WT mice, $n=25$ in vehicle-treated A $\beta P P 23$ mice, $n=5$ in Am80-treated A $\beta P P 23$ mice, $n=7$ in HX630treated A $\beta P P 23$ mice, $n=17$ in Am80/HX630-treated A $\beta P P 23$ mice). B) Scatterplot and Pearson correlation analyses were used to determine the relationship between IL-4 values in the hippocampus and the percent time spent in the target quadrant, for vehicle- (Ba), and Am80/HX630treated A $\beta P P 23$ mice $(\mathrm{Bb})$. C) At 18 days after beginning treatment with Am80 $(0.5 \mathrm{mg} / \mathrm{mg} / \mathrm{d})$ and $\mathrm{HX} 630(5 \mathrm{mg} / \mathrm{kg} / \mathrm{d}), \mathrm{levels}$ of $\mathrm{A} \beta_{42}$ in TBS-insoluble fractions of the hippocampus were determined via sandwich ELISA. ${ }^{*} p<0.05$ by Student's $t$-test.

significantly in Am80/HX630-treated AßPP23 mice compared with the vehicle-treated group (Fig. 3C; $p<0.05)$. The Ide mRNA level also showed a slight increase in HX630-treated A $3 P P 23$ mice, but this was not statistically significant (Fig. 3C; $p=0.062$ ). These results suggest that IDE and NEP may be involved in the increased $A \beta$ clearance in $\mathrm{A} \beta \mathrm{PP} 23$ mice treated with Am80/HX630.

\section{Am80/HX630 and HX630 increased clearance activity of oligomeric $A \beta$ peptide in rat primary microglia}

We next investigated whether or not Am80 and HX630 increase phagocytotic activity of oligomeric A $\beta$ peptide in microglia in vitro (Fig. 4). Recently,
Yamanaka et al. [44] reported that a peroxisome proliferator-activated receptor (PPAR) $\gamma$ agonist plus an RXR agonist additively upregulated CD36 expression and enhanced microglial uptake of $A \beta$ peptide. CD36 expression was increased 1.3-fold by HX630 treatment, but was not increased in Am80/HX630treated cells (Fig. 4A). Similar results were also observed in vivo (as shown in Fig. 3A). Cd36 is a target gene of PPAR $\gamma / \mathrm{RXR}$ [45]. The increase in CD36 expression by HX630 in microglia was inhibited by co-incubation with the PPAR $\gamma$ antagonist GW9662 (Fig. 4A), indicating that HX630-induced CD36 expression is PPAR $\gamma / \mathrm{RXR}$-dependent. IDE was increased significantly only after co-treatment with Am80/HX630 (Fig. 4A). HX630 and Am80/HX630 increased degradation activity towards ${ }^{125}$ I-labeled 

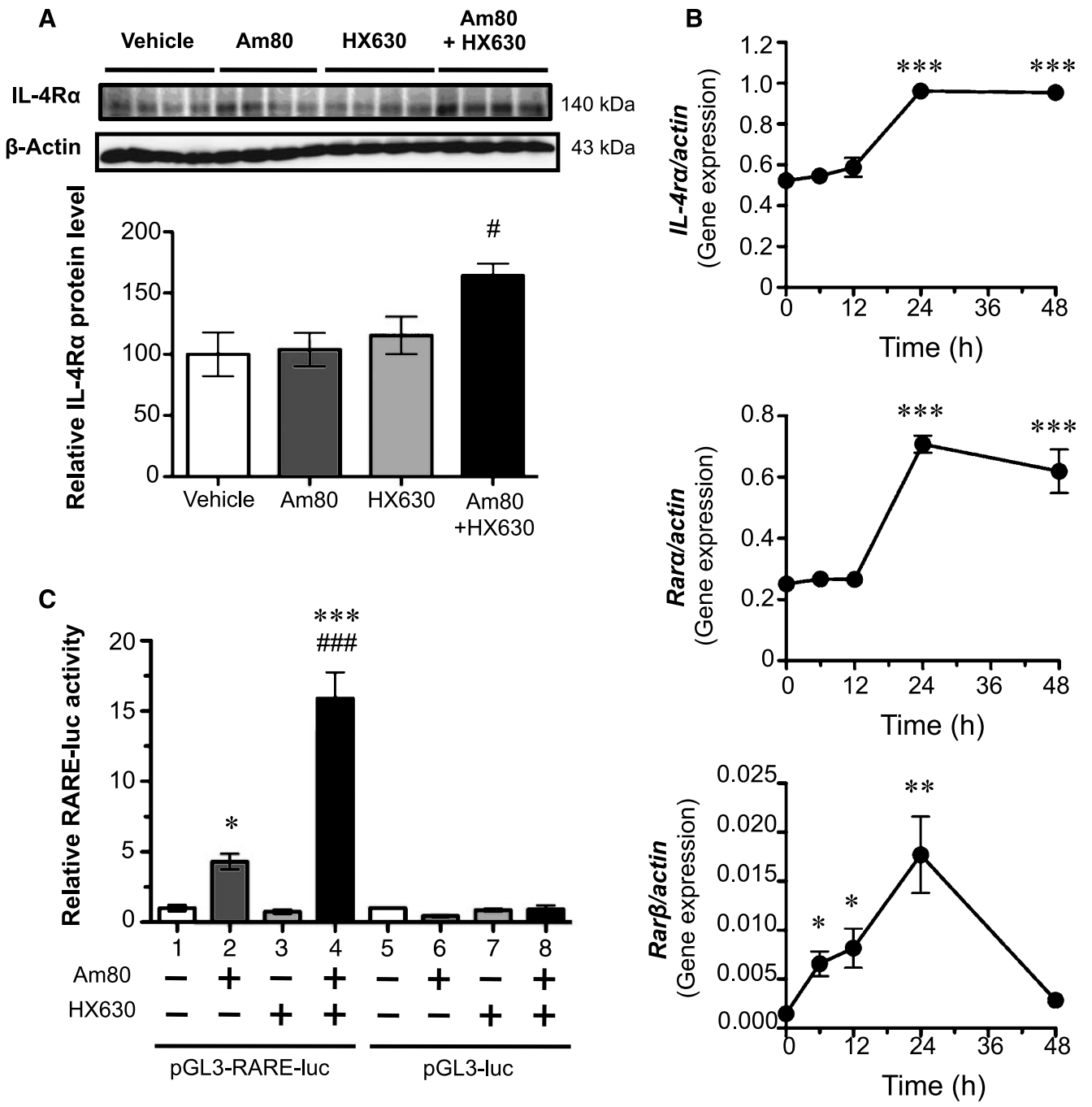

Fig. 6. Am80 with HX630 synergistically increased IL-4R $\alpha$ protein and RARE reporter activity in mouse microglial MG5 cells. A) MG5 cells were incubated for $48 \mathrm{~h}$ with Am80 $(5 \mu \mathrm{M})$ and/or HX630 $(5 \mu \mathrm{M})$. Cell proteins $(30 \mu \mathrm{g})$ were subjected to immunoblot analysis with antibodies to IL-4R $\alpha$ and $\beta$-actin. Densitometric scanning was used to quantify results. Values were normalized to $\beta$-actin expression and expressed relative to the vehicle-treated cells. Error bars represent means $\pm \operatorname{SEM}(n=4) .{ }^{*} p<0.05$ by Dunnett's multiple comparison test, relative to the vehicletreated cells. B) RNA from MG5 cells treated with Am80 $(5 \mu \mathrm{M})$ plus HX630 $(5 \mu \mathrm{M})$ for indicated periods was subjected to quantitative RT-PCR with specific primers for Il-4r , Rar $\alpha, \operatorname{Rar} \beta$, and $\beta$-actin genes. Total RNA from mouse liver was used as the calibrator sample for $I l-4 r \alpha$, $\operatorname{Rar} \alpha, \operatorname{Rar} \beta$, and $\beta$-actin genes. Values were normalized to $\beta$-actin gene expression. Error bars represent means $\pm \mathrm{SEM}(n=4)$. ${ }^{* * *} p<0.001$, ${ }^{* *} p<0.01$, and ${ }^{*} p<0.05$ by Student's $t$-test, relative to the untreated cells. C) Cells were transfected with the pGL3-RARE-Luc or pGL3-Luc reporter plasmid together with a phRL-TK internal control and were treated with Am80 (5 $\mu \mathrm{M})$ and/or HX630 (5 $\mu \mathrm{M})$. Luciferase activity in the cell extract was normalized to Renilla luciferase activity and was expressed as fold induction relative to the vehicle-treated cells. Error bars represent means $\pm \operatorname{SEM}(n=4) .{ }^{* * *} p<0.001$ and ${ }^{*} p<0.05$ by Dunnett's multiple comparison test, relative to the vehicle-treated cells (column 1). ${ }^{\# \# ~} p<0.001$ by Dunnett's multiple comparison test, relative to the Am80-treated cells (column 2).

oligomeric $A \beta_{1-42}\left(\mathrm{o}-\mathrm{A} \beta_{1-42}\right)$ in rat primary microglia, compared with vehicle-treated cells, and the increase was inhibited by fucoidan, a scavenger receptor inhibitor, in each case (Fig. 4B). The cell-association and degradation activities in Am80/HX630-treated cells were also inhibited by insulin, an IDE inhibitor
(Fig. 4C, D). The NEP inhibitor thiorphan did not affect the degradation activity in Am80/HX630-treated cells (Fig. 4D). Thus, scavenger receptor-mediated uptake, intracellular degradation and $\mathrm{A} \beta$ catabolism by IDE (in cytosol and/or on plasma membrane) are important for Am80/HX630-induced clearance of o-A $\beta_{1-42}$. 
Improvement in memory of Am80/HX630-treated $A \beta P P 23$ mice is correlated with IL-4 levels in the hippocampus

We next investigated whether Am80/HX630induced memory improvement is related to reduced neuroinflammation, especially changes in levels of anti-inflammatory cytokine IL-4, in the cerebral cortex and hippocampus (Fig. 5). Although the IL-4 level in the cortex was indistinguishable in vehicletreated WT and A $\beta P P 23$ mice, the hippocampal IL-4 level was significantly higher in A $\beta P P 23$ mice than in WT mice (Fig. 5A; $p<0.05$ ). HX630 and Am80/HX630 treatments increased the hippocampal IL-4 levels of A $\beta P P 23$ mice, but the increase was statistically insignificant (Fig. 5A; $p=0.096$ and $p=0.087$, respectively). However, the hippocampal IL4 level in Am80/HX630-treated A $\beta$ PP23 mice showed a significant positive relationship with memory in the MWM test (Fig. 5Bb; $p=0.007, r=0.625$ ). No such correlation was observed for groups treated with vehicle or a single retinoid (Fig. 5Ba, Supplementary Figure 3). The vehicle-treated WT mice also showed a positive correlation between the hippocampal IL-4 level and the MWM memory test performance $(p=0.072, r=0.772$ for target occupancy, $p=0.033$, $r=0.849$ for crossings over the target annulus) (Supplementary Figure 4A, B).

Hippocampal levels of insoluble $A \beta_{42}$ were decreased in Am80/HX630-treated AßPP23 mice (Fig. 5C). These results suggest that memory performance may depend upon the efficiency of IL-4 signaling, not the cytokine levels (Fig. 5A), and that Am80/HX630-induced co-activation of RAR $\alpha, \beta /$ RXRs improves IL-4 signaling.

\section{Am80 and HX630 synergistically increased IL-4R $\alpha$ expression in mouse microglial MG5 cells}

To investigate whether the combination of Am80 and HX630 increases the expression of IL-4 receptor $\alpha$ chain (IL-4R $\alpha$ ) in microglial cells, we examined their effects in vitro on mouse microglial MG5 cells (Fig. 6). Am80 and HX630 alone did not increase IL-4R $\alpha$ levels, but their combination did result in an increase of IL-4R $\alpha$ (Fig. 6A). IL-4R $\alpha$ mRNA in MG5 cells was also increased 24-48 hours after Am80/HX630 co-treatment (Fig. 6B). RA response element (RARE) reporter activity in MG5 cells was increased 4.3-fold after Am80 treatment (Fig. 6C), but no increase was seen after HX630 treatment. However, this activity showed a marked increase (15.9-fold) after co-treatment with HX630 and Am80 (Fig. 6C). In contrast, Am80/HX630 had no effect on the luciferase activity of the control pGL3-luc vector, as expected (Fig. 6C). These results indicate that HX630 has an RAR-synergistic effect in MG5 cells and that marked RAR activity induced by Am80/HX630 may be involved in IL-4R $\alpha$ upregulation in MG5 cells.

\section{DISCUSSION}

Our present results demonstrate that oral coadministration of HX630 (5 mg/kg) and Am80 $(0.5 \mathrm{mg} / \mathrm{kg})$ for 17 days ameliorated learning deficits in 8.5-month-old A $\beta P P 23$ mice (Fig. 1) and significantly reduced brain levels of insoluble $A \beta_{42}$ and $A \beta_{40}$ (Fig. 2). Administration of Am80 alone at higher dose ( $3 \mathrm{mg} / \mathrm{kg} / \mathrm{d}$ or $6 \mathrm{mg} / \mathrm{kg} / \mathrm{d}$ for 17 days) neither reduced A $\beta$ levels nor improved cognitive deficits in A $\beta$ PP23 mice (Supplementary Figure 5, data not shown).

In contrast, Ding et al. [14] demonstrated that administration of RARs agonist ATRA alone improved memory function in A $\beta P P / P S 1$ mice. However, ATRA is shown to isomerize to the 9-cis isomer in vitro [46], which is a potent RARs/RXRs dual agonist, whereas synthetic retinoid Am80 is not converted to derivatives with RXR affinity [47]. Solomin et al. [48], using an RXR-specific reporter transgene, have provided evidence that ATRA $(20 \mathrm{mg} / \mathrm{kg})$ activates RXR in vivo. An RXR-selective agonist, bexarotene $(100 \mathrm{mg} / \mathrm{kg}$, p.o.), improved behavioral defects in A $\beta P P / P S 1$ mice [16], but it displays cross-reactivity with RARs at higher concentrations [49]. Shudo et al. [13] previously reported that co-administration of Am80/HX630 efficiently ameliorates memory deficits in scopolaminetreated rats, a model of the main clinical symptom of $\mathrm{AD}$. Therefore, it is reasonable to consider that effective memory improvement by retinoids may require RARs/RXRs co-activation. Participation of RAR $\gamma$ is not required for this retinoid-induced improvement in memory deficits, because Am80 is specific for RAR $\alpha$ and RAR $\beta$ and hardly binds to RAR $\gamma$ [50]. Consideration of retinoid receptor selectivity is therefore important for the therapeutic use of retinoids.

Co-administration of Am80 with HX630 reduced the brain level of insoluble, but not soluble, $A \beta$ in AßPP23 mice (Fig. 2). Soluble (TBS-extractable) $\mathrm{A} \beta$ is localized mainly in neurons, whereas insoluble $A \beta$ accumulates in extracellular plaques that are formed via oligomers or protofibrils [41, 51]. It is thought that both intracellular and extracellular $\mathrm{A} \beta$ oligomers contribute to the pathology of $\mathrm{AD}$ 
[52]. Tomiyama and colleagues [52] showed that intraneuronal $A \beta$ oligomers are fractionated predominantly into TBS-insoluble fractions, particularly the formic acid-extracted fraction, in A $\beta P P$ transgenic mice expressing the E693 $\Delta$ mutation, and contribute to $A D$ via enhanced $A \beta$ oligomerization without fibrillization. Our results here indicate that the apparent reduction of insoluble $A \beta$ correlates well with memory improvement in $\mathrm{A} \beta \mathrm{PP} 23$ mice. Mechanisms that may lead to reduced insoluble $A \beta$ s consisting intracellular/extracellular $A \beta$ oligomers and extracellular $A \beta$ plaques include the following: (1) increased expression of A $\beta$-degrading enzymes such as NEP and IDE in neurons and glial cells, and (2) increased internalization or clearance of oligomeric $A \beta s$ mainly in microglia. We demonstrated here that these two mechanisms are both functional in retinoid ligand-treated A $\beta$ PP23 mice.

With regard to the first mechanism, we found that Am80/HX630 treatment increased the expression of the $\mathrm{A} \beta$-degrading enzymes IDE and NEP in vivo (Fig. 3). We also observed that Am80/HX630 treatment increased both NEP and IDE in murine N1E115 neuronal cells, and increased NEP in murine A1 glial cells (Supplementary Figure 6). IDE transcription is regulated by RA; the Ide gene contains a RARE in its promoter region [53]. We found that Am80/HX630 significantly increased Ide mRNA in AßPP23 mice (Fig. 3C). In addition, HX630 tended to increase Ide mRNA in AßPP23 mice (Fig. 3C; $p=0.062$ ). It is of note that membrane-associated IDE was increased in Am80/HX630- and HX630-treated AßPP23 mice, in parallel with the increase of Ide mRNA (Fig. 3B, $\mathrm{C})$, although the IDE level in whole brain lysates was unchanged (Fig. 3A). It has been reported that there are two pools of IDE: a cytosolic pool with a longer half-life and a plasma membrane pool that shows faster turn-over [54]. The membrane-bound IDE protein level is important because its level is related to the clearance of $A \beta$ plaques in $A \beta P P$ transgenic mice [55] and its decrease in the brain of individuals is associated with a high risk of developing $\mathrm{AD}$ [56]. Therefore, the increase in membrane-associated IDE that we observed is considered to contribute to A $\beta$ clearance in Am80/HX630-treated A $\beta P P 23$ mice. Qui et al. [57] showed that BV2 microglial cells secrete IDE, which mediates the degradation of $A \beta$ peptides in the extracellular milieu. In addition, Goncalves and coworkers [17] showed that IDE activity in the medium was increased in murine microglial cells treated with Am580, an isomer of Am80. Therefore, there is a possibility that IDE is released extracellularly after Am80/HX630 treatment, although the activity in the medium could not be determined in our cell assay system.

NEP, another A $\beta$-degrading enzyme, was also increased after treatment with Am80, HX630, and their combination in A $\beta P P 23$ mice (Fig. 3A). The Mme/Nep mRNA level, however, was unaffected by these retinoids in vivo and in vitro (Supplementary Figure 7, data not shown), which suggests that retinoids increase either the translation of Mme/Nep mRNA or the stability of the NEP protein. RA reportedly increased $\mathrm{RAR} \alpha$-mediated translation of glutamate receptor 1 mRNA in hippocampal neurons [58, 59], and RAR $\alpha$ was present in nuclei and dendrites of hippocampal CA1 pyramidal neurons [59], where NEP immunoreactivity was detected in A $\beta P P 23$ mice [60]. Our results suggest that increased expression of NEP may also contribute to reduction of insoluble $A \beta$ in brain, although NEP expression is not specifically increased by co-administration of Am80/HX630.

It remains unknown whether neprilysin is a target gene of RAR or RXR. It has been reported that neprilysin is a target gene of PPAR $\delta / R X R$ [61]. It is possible that upregulation of neprilysin by HX630 treatment may depend on PPAR $\delta / R X R$ activation. In this study, we showed that Am80 as well as Am80/HX630 increased the expression of neprilysin in A $\beta P P 23$ mice. Further studies are required to elucidate whether neprilysin is a direct target gene of RAR/RXR.

Apropos the second mechanism, we found that HX630 and Am80/HX630 increased phagocytotic activity for oligomeric $\mathrm{A} \beta$ peptide in microglia in vitro (Fig. 4B). Therefore, increased microglial degradation and clearance of $A \beta s$ contribute to the reduction of insoluble $A \beta$ in A $\beta P P 23$ mice after HX630 and Am80/HX630 treatments. Recently, Yamanaka et al. [44] reported that a PPAR $\gamma$ agonist plus an RXR agonist additively upregulated CD36 expression and enhanced microglial uptake of $\mathrm{A} \beta$ peptides. HX630 treatment increased CD36 protein level in microglia (Fig. 4A), suggesting that CD36 may be involved in $A \beta$ clearance in HX630-treated microglia. However, the HX630-induced increase of CD36 expression was abolished by co-treatment with Am80 in vitro (Fig. 4A) and in vivo (Fig. 3A). In addition, the Cd36 mRNA level was decreased in Am80/HX630treated AßPP23 mice (Supplementary Figure 7). We also observed that co-addition of GW9662, a PPAR $\gamma$ antagonist, with HX630 disturbed the HX630-induced CD36 upregulation in microglia (Fig. 4A). Based on these results, we initially speculated that Am80 might block RXR/PPAR $\gamma$ activation by HX630. However, Am80 has been suggested [62] to inhibit Cd36 tran- 
scription in macrophages via mechanisms that are independent of PPAR $\gamma$, because Am80 does not affect the reporter activity of PPAR $\gamma$ response element. The possibility remains that the Am80-RAR $\alpha / \beta$ complex may outcompete PPAR $\gamma$ for RXR. Thus, the precise mechanism(s) of Am80 inhibition of HX630-induced CD36 expression remains to be solved. We also demonstrated that IDE expression was increased in Am80/HX630-treated microglia, where CD36 expression was decreased (Fig. 4A). The increase of $\mathrm{A} \beta$ clearance activity was inhibited by insulin and fucoidan (Fig. 4C). These results indicate that IDE contributes to the Am80/HX630-induced increase of $A \beta$ clearance by enhancing $A \beta$ degradation in microglia.

Thus, we have shown that several factors-A $\beta$ degradation or $A \beta$ clearance systems involving IDE and NEP - are implicated in the reduction of insoluble $\mathrm{A} \beta$ and the improvement in memory that we observed in Am80/HX630-treated AßPP23 mice. All these factors together may be responsible for these effects, though we cannot yet assign a priority order for their contributions.

Regarding the participation of inflammation-related cytokines, the hippocampal IL-4 levels and MWM memory test performance showed a significant positive correlation in Am80/HX630-treated A $3 P$ P23 mice (Fig. 5Bb), whereas no such correlation was found in the vehicle-treated A $\beta P P 23$ mice group. The vehicle-treated A $\beta P P 23$ mice also had higher levels of hippocampal IL-4 than did vehicle-treated WT mice with normal memory function (Fig. 5A), suggesting that functional IL-4 signaling may be impaired in hippocampus of 8.5-month-old A $\beta P P 23$ mice, and that the A $\beta P P 23$ mice produce more IL-4 to compensate for the functional defect. We previously showed that intracerebral microinjection of IL-4/IL-13 reduced $\mathrm{A} \beta$ levels and improved cognitive deficits in A $\beta \mathrm{PP} 23$ mice, possibly by activating IL- $4 \mathrm{R} \alpha$-positive M2like microglia [63]. Th2-biased immune responses induced by retinoids may serve to restore IL-4 signaling [23]. A candidate target gene that is impaired in $\mathrm{A} \beta \mathrm{PP} 23$ mice is IL- $4 \mathrm{R} \alpha$, as has been reported for aged mice [64]. Immunohistochemical staining showed that IL-4R $\alpha$ was expressed in the hippocampus (Supplementary Figure 8A), as previously reported [65]. Moreover, the IL-4R $\alpha$ protein level in the membrane fraction of whole brain, including hippocampus, was increased in Am80/HX630-treated AßPP23 mice compared to the vehicle-treated group (Supplementary Figure 8B). We found here that Am80/HX630 increased IL-4R $\alpha$ expression in microglial MG5 cells (Fig. 6A,B). Also, HX630 synergistically potentiated
Am80-induced RAR activation in MG5 cells (Fig. 6C). Therefore, Am80/HX630 may promote differentiation of IL-4-responsive M2-like microglia and increase their clearance activity for oligomeric $A \beta$ peptides by restoring impaired IL-4 signaling in A $\beta P P 23$ mice. The present results are consistent with reports that alternative microglial activation via IL-4 signaling is impaired in $\mathrm{AD}$ [3].

We have not determined whether IL- $4 \mathrm{R} \alpha$ is a target gene of either RAR or RXR. However, Zhu and colleagues [66] showed that ATRA markedly increased mRNAs encoding RAR $\beta$ and IL-4R $\alpha$ in murine dendritic cells, and RAR $\beta$ bound directly with the promoter region of IL-4R $\alpha$ following ATRA treatment [66]. As shown in Fig. 6B, Rar $\beta$ mRNA was increased $6 \mathrm{~h}$ after Am80/HX630 treatment and reached a maximum at $24 \mathrm{~h}$ in murine MG5 microglial cells. On the other hand, $I L-4 R \alpha$ mRNA was expressed before treatment, then began to increase at $24 \mathrm{~h}$ after treatment, and remained little changed up to $48 \mathrm{~h}$. These results suggest that the IL-4R $\alpha$ induction is mediated by RAR $\beta$ in Am80/HX630-treated cells. The Rar $\alpha$ gene contains RARE motifs in its promoter region [67, 68], and Rar $\alpha$ mRNA was also increased at $24-48 \mathrm{~h}$ after Am80/HX630 treatment (Fig. 6B). In Am80-treated MG5 cells, RARE-reporter activity was increased, but IL-4R $\alpha$ protein expression remained unchanged (Fig. 6A, 6C). IDE protein, another target gene of RAR/RXR was increased by Am80/HX630, but not by Am80 in MG5 cells and rat microglia (Fig. 4A, Supplementary Figure 9). These results suggest that co-activation of RAR/RXR might be required for efficient protein expression of RAR/RXR target genes in microglia.

Proinflammatory cytokines have been implicated in sickness-associated behaviors, aging, and autoimmunity [25], whereas cytokines associated with classical inflammation are required for many aspects of CNS function, such as synaptic scaling through glial TNF$\alpha$ [69]. We observed that hippocampal TNF- $\alpha$ levels also showed a positive correlation with memory test performance in Am80/HX630-treated AßPP23 mice (Supplementary Figures 10Bd, 11Cd), but not in the vehicle-treated group (Supplementary Figures 10Ba, $11 \mathrm{Ca}$ ). Levels of hippocampal mRNAs for Tnfrl and 2 in A $\beta$ PP23 mice were higher than those in WT mice (Supplementary Figure 12A,B). Therefore, we believe that TNF- $\alpha$ signaling, not TNF- $\alpha$ amount (Supplementary Figure 10A), may be impaired in A $\beta P P 23$ mice. The present result is also consistent with reports that homeostatic synaptic scaling via TNF- $\alpha$ signaling is impaired in AD [70, 71]. 
In the present study, the hippocampal TNF- $\alpha$ level in Am80-treated A $\beta P P 23$ mice showed a positive relationship with memory in the MWM test $(p=0.084$, $r=0.827$ for target occupancy, $p=0.055, r=0.870$ for crossings over the target annulus) (Supplementary Figures $10 \mathrm{Bb}, 11 \mathrm{Cb}$ ). However, Am80 treatment did not ameliorate memory deficits in A $\beta P P 23$ mice (Fig. 1), which suggests that improved hippocampal TNF- $\alpha$ signaling is important but not sufficient for memory improvement in 8.5-month-old A $\beta P P 23$ mice. Consequently, co-activation of RAR and RXR by co-administration of Am80 with HX630 may ameliorate memory deficits in A $\beta P P 23$ mice by improving both TNF- $\alpha$ and IL-4 signaling. However, further study is needed to confirm this idea.

The present in vivo data are not consistent with the in vitro study of Dheen et al. [72], who reported that $A \beta$ peptide activates TNF- $\alpha$ expression, and also that this activation is reduced by ATRA treatment. However, the inhibitory effect of ATRA on TNF- $\alpha$ production was only moderate (about $40-50 \%$ ), in contrast to its complete inhibition of nitric oxide production [72, 73]. In an AD model mouse, loss of both TNFR1 and TNFR2 exacerbates the pathogenesis and reduces $A \beta$ phagocytic activity in microglia, indicating that intact TNF- $\alpha$ receptor signaling is critical for microglialmediated uptake of the extracellular $A \beta$ peptide pool [71]. Overall, these reports suggest that TNF- $\alpha$ produced by activated microglial cells is pleiotropic and may be either neuroprotective or neurotoxic depending on several factors, for example, which type of TNF receptor is activated $[71,74]$.

In this study, we observed that $\operatorname{RAR} \alpha$ is located in nuclei of microglia, but is dispersed throughout astrocytes in A $\beta P P 23$ mice (Supplementary Figure 2). Thus, when microglia accumulate around $A \beta$ plaques in $\mathrm{A} \beta \mathrm{PP} 23$ mice, their $\mathrm{RAR} \alpha$ appears to be activated, and $A \beta$ clearance is increased. However, the ability of microglia to clear $A \beta$ is considered to decrease with age and progression of AD pathology [75]. Goncalves et al. [17] recently showed that $\mathrm{RAR} \alpha$ signaling is down-regulated by $A \beta$, which inhibits the synthesis of the endogenous ligand, RA, in A $\beta P P$ mice (Tg2576). Although we observed nuclear translocation of RAR $\alpha$ in microglia of A $\beta P P 23$ mice, this may be insufficient to enable transcriptional activation by endogenous RA in the mice, and exogenous Am80 may be required to achieve activation. We did not examine whether transcriptional activation of RAR $\alpha$ is decreased in A $\beta P P 23$ mice compared to their WT littermates. However, we observed that the expression level of mRNA for tissue-plasminogen activator (tPA), one of the genes controlled by RAR/RXR, tended to be lower than that in WT littermates $(p=0.080$, Supplementary Figure 13B), whereas it was significantly increased in Am80/HX630-treated AßPP23 mice compared to vehicle-treated A $\beta P P 23$ mice (Supplementary Figure 13B). Moreover, Ide is a target gene of RAR/RXR, and Ide mRNA was decreased in microglia of A $\beta P P / P S 1$ mice at the age of 8 months, compared to that in microglia of their WT littermates [75]. Further study is needed to investigate whether the expression levels of RAR $\alpha$-target genes in microglia are decreased in A $\beta P P 23$ mice and whether they are increased by Am80/HX630 administration in vivo.

It is not clear whether Am80 and HX630 cross the blood-brain barrier and directly or indirectly affect the brain. It is known that Am580, an isomer of Am80, crosses the blood-brain barrier in mice [17]. Am80 has been reported to attain some extent of access into the brain: cerebral tissue content of Am80 in normal male rats reaches around $100 \mathrm{pmol} / \mathrm{g}$ tissue at $2 \mathrm{~h}$ after subcutaneous administration of the drug at $1 \mathrm{mg} / \mathrm{kg}$, then decreased at $6 \mathrm{~h}$, and returned to the control levels at $24-120 \mathrm{~h}[76,77]$. $\operatorname{Rar} \beta$ is a target gene of RAR/RXR, and $\operatorname{Rar} \beta$ mRNA was not increased by Am80/HX630 treatment in vivo (Supplementary Figure 13A), in contrast to the in vitro study (Fig. 6). Because brain tissues were sampled at 1 day after last administration of the compounds, the concentration is considered not to be enough to increase $\operatorname{Rar} \beta$ mRNA expression at the time point. The expression level of $\operatorname{Rar} \beta$ mRNA may be tightly regulated (probably by a transcription factor), or the half-life of $\operatorname{Rar} \beta$ mRNA may be short in vivo. On the other hand, the expression of Ide, another RAR/RXR-target gene, was increased by Am80/HX630 treatment in vivo as well as in vitro (Figs. 3C, 4A). Moreover, mRNA for $t P A$, another target gene of RAR/RXR, was also increased by Am80/HX630 co-administration (Supplementary Figure 13B). mRNA and protein of $C d 36$, a target gene of PPAR $\gamma / \mathrm{RXR}$, were increased by HX630 treatment both in vitro and in vivo (Figs. 3A, 4A). These results suggest that Am80 and HX630 might cross the blood-brain barrier and act directly in the brain.

Finally, we should mention that Goncalves et al. [17] recently reported that Am580 (an Am80 isomer with a reversed amide bond) ameliorated cognitive deficits (Tmaze spontaneous alternation and Nest building tests) in Tg2576 mice, another AD model. Although the method of administration, kinds of behavioral experiments, and AD model were different from ours, we speculate that combined treatment with Am580 and an 
RXR ligand might also be synergistically more effective on memory deficits (MWM) in their model.

In conclusion, co-administration of Am80/HX630 effectively reduces insoluble $\mathrm{A} \beta$ peptides and improves cognitive deficits in A $\beta P P 23$ mice. Combination treatment with RAR and RXR agonists, therefore, may be an effective approach for AD therapy.

\section{ACKNOWLEDGMENTS}

This work was supported by Grants-in-Aid for Scientific Research 19390031 (to H.N.) and 21790114, 23790133, 25460150 (to K.K.) from the Ministry of Education, Culture, Sports, Science and Technology of Japan. We thank Dr. M. Staufenbiel (Novartis Institutes, Basel) for providing A $\beta P P 23$ mice.

Authors' disclosures available online (http://www.jalz.com/disclosures/view.php?id=2274).

\section{SUPPLEMENTARY MATERIAL}

Supplementary figures are available in the electronic version of this article: http://dx.doi.org/10.3233/JAD132720.

\section{REFERENCES}

[1] Krstic D, Knuesel I (2013) Deciphering the mechanism underlying late-onset Alzheimer's disease. Nat Rev Neurol 9, 25-34.

[2] Vom Berg J, Prokop S, Miller KR, Obst J, Kälin RE, Lopategui-Cabezas I, Wegner A, Mair F, Schipke CG, Peters O, Winter Y, Becher B, Heppner FL (2012) Inhibition of IL-12/IL-23 signaling reduces Alzheimer's disease-like pathology and cognitive decline. Nat Med 18, 1812-1819.

[3] Heneka MT, Kummer MP, Stutz A, Delekate A, Schwartz S, Vieira-Saecker A, Griep A, Axt D, Remus A, Tzeng TC, Gelpi E, Halle A, Korte M, Latz E, Golenbock DT (2013) NLRP3 is activated in Alzheimer's disease and contributes to pathology in APP/PS1 mice. Nature 493, 674-678.

[4] Sporn MB, Roberts AB, Goodman DS, Gudas LJ (1994) The Retinoids: Biology, Chemistry, and Medicine, 2nd ed, Raven Press, New York.

[5] Corcoran JP, So PL, Maden M (2004) Disruption of the retinoid signalling pathway causes a deposition of amyloid $\beta$ in the adult rat brain. Eur J Neurosci 20, 896-902.

[6] Prinzen C, Müller U, Endres K, Fahrenholz F, Postina R (2005) Genomic structure and functional characterization of the human ADAM10 promoter. FASEB J 19, 1522-1524.

[7] Tippmann F, Hundt J, Schneider A, Endres K, Fahrenholz F (2009) Up-regulation of the $\alpha$-secretase ADAM10 by retinoic acid receptors and acitretin. FASEB $J$ 23, 1643-1654.

[8] Jarvis CI, Goncalves MB, Clarke E, Dogruel M, Kalindjian SB, Thomas SA, Maden M, Corcoran JP (2010) Retinoic acid receptor- $\alpha$ signalling antagonizes both intracellular and extracellular amyloid- $\beta$ production and prevents neuronal cell death caused by amyloid- $\beta$. Eur J Neurosci 32, 1246-1255.
[9] Koryakina A, Aeberhard J, Kiefer S, Hamburger M, Küenzi P (2009) Regulation of secretases by all-trans-retinoic acid. FEBS J 276, 2645-2655.

[10] Lichtenthaler SF (2011) $\alpha$-Secretase in Alzheimer's disease: Molecular identity, regulation and therapeutic potential. J Neurochem 116, 10-21.

[11] Endres K, Fahrenholz F (2012) Regulation of $\alpha$-secretase ADAM10 expression and activity. Exp Brain Res 217, 343352.

[12] Goodman AB, Pardee AB (2003) Evidence for defective retinoid transport and function in late onset Alzheimer's disease. Proc Natl Acad Sci U S A 100, 2901-2905.

[13] Shudo K, Kagechika H, Yamazaki N, Igarashi M, Takeda C (2004) A synthetic retinoid Am80 (tamibarotene) rescues the memory deficit caused by scopolamine in a passive avoidance paradigm. Biol Pharm Bull 27, 1887-1889.

[14] Ding Y, Qiao A, Wang Z, Goodwin JS, Lee ES, Block ML, Allsbrook M, McDonald MP, Fan GH (2008) Retinoic acid attenuates $\beta$-amyloid deposition and rescues memory deficits in an Alzheimer's disease transgenic mouse model. J Neurosci 28, 11622-11634.

[15] Kawahara K, Nishi K, Suenobu M, Ohtsuka H, Maeda A, Nagatomo K, Kuniyasu A, Staufenbiel M, Nakagomi M, Shudo K, Nakayama H (2009) Oral administration of synthetic retinoid Am80 (Tamibarotene) decreases brain $\beta$ amyloid peptides in APP23 mice. Biol Pharm Bull 32, 1307-1309.

[16] Cramer PE, Cirrito JR, Wesson DW, Lee CY, Karlo JC, Zinn AE, Casali BT, Restivo JL, Goebel WD, James MJ, Brunden KR, Wilson DA, Landreth GE (2012) ApoE-directed therapeutics rapidly clear $\beta$-amyloid and reverse deficits in $A D$ mouse models. Science 335, 1503-1506.

[17] Goncalves MB, Clarke E, Hobbs C, Malmqvist T, Deacon R, Jack J, Corcoran JP (2013) Amyloid $\beta$ inhibits retinoic acid synthesis exacerbating Alzheimer disease pathology which can be attenuated by an retinoic acid receptor $\alpha$ agonist. Eur J Neurosci 37, 1182-1192.

[18] Fitz NF, Cronican AA, Lefterov I, Koldamova R (2013) Comment on "ApoE-directed therapeutics rapidly clear $\beta$-amyloid and reverse deficits in AD mouse models". Science 340, 924-c.

[19] Price AR, Xu G, Siemienski ZB, Smithson LA, Borchelt DR, Golde TE, Felsenstein KM (2013) Comment on "ApoEdirected therapeutics rapidly clear $\beta$-amyloid and reverse deficits in AD mouse models". Science 340, 924-d.

[20] Tesseur I, Lo AC, Roberfroid A, Dietvorst S, Van Broeck B, Borgers M, Gijsen H, Moechars D, Mercken M, Kemp J, D'Hooge R, De Strooper B (2013) Comment on "ApoEdirected therapeutics rapidly clear $\beta$-amyloid and reverse deficits in AD mouse models". Science 340, 924-e.

[21] Veeraraghavalu K, Zhang C, Miller S, Hefendehl JK, Rajapaksha TW, Ulrich J, Jucker M, Holtzman DM, Tanzi RE, Vassar $\mathrm{R}$, Sisodia SS (2013) Comment on "ApoE-directed therapeutics rapidly clear $\beta$-amyloid and reverse deficits in AD mouse models". Science 340, 924-f.

[22] LaClair KD, Manaye KF, Lee DL, Allard JS, Savonenko AV, Troncoso JC, Wong PC (2013) Treatment with bexarotene, a compound that increases apolipoprotein-E, provides no cognitive benefit in mutant APP/PS1 mice. Mol Neurodegener $\mathbf{8}$, 18.

[23] Ross AC (2012) Vitamin A and retinoic acid in T cell-related immunity. Am J Clin Nutr 96, 1166S-1172S.

[24] Iwata M, Eshima Y, Kagechika H (2003) Retinoic acids exert direct effects on $\mathrm{T}$ cells to suppress Th1 development and enhance $\mathrm{Th} 2$ development via retinoic acid receptors. Int Immunol 15, 1017-1025. 
[25] Gadani SP, Cronk JC, Norris GT, Kipnis J (2012) IL-4 in the brain: A cytokine to remember. J Immunol 189, 4213-4219.

[26] Derecki NC, Cardani AN, Yang CH, Quinnies KM, Crihfield A, Lynch KR, Kipnis J (2010) Regulation of learning and memory by meningeal immunity: A key role for IL-4. J Exp Med 207, 1067-1080.

[27] Delescluse C, Cavey MT, Martin B, Bernard BA, Reichert U, Maignan J, Darmon M, Shroot B (1991) Selective high affinity retinoic acid receptor alpha or beta-gamma ligands. Mol Pharmacol 40, 556-562.

[28] Amano Y, Noguchi M, Nakagomi M, Muratake H, Fukasawa H, Shudo K (2013) Design, synthesis and evaluation of retinoids with novel bulky hydrophobic partial structures. Bioorg Med Chem 21, 4342-4350.

[29] Ishida S, Shigemoto-Mogami Y, Kagechika H, Shudo K, Ozawa S, Sawada J, Ohno Y, Inoue K (2003) Clinically potential subclasses of retinoid synergists revealed by gene expression profiling. Mol Cancer Ther 2, 49-58.

[30] Nishimaki-Mogami T, Tamehiro N, Sato Y, Okuhira K, Sai K, Kagechika H, Shudo K, Abe-Dohmae S, Yokoyama S, Ohno Y, Inoue K, Sawada J (2008) The RXR agonists PA024 and HX630 have different abilities to activate LXR/RXR and to induce ABCA1 expression in macrophage cell lines. Biochem Pharmacol 76, 1006-1013.

[31] Kagechika H, Kawachi E, Hashimoto Y, Shudo K (1984) New type inducers of differentiation of human HL-60 promyelocytic leukemia cells. Terephthalic anilides. Chem Pharm Bull 32, 4209-4212.

[32] Umemiya H, Fukasawa H, Ebisawa M, Eyrolles L, Kawachi E, Eisenmann G, Gronemeyer H, Hashimoto Y, Shudo K, Kagechika H (1997) Regulation of retinoidal actions by diazepinylbenzoic acids. Retinoid synergists which activate the RXR-RAR heterodimers. J Med Chem 40 , 4222-4234.

[33] Sturchler-Pierrat C, Abramowski D, Duke M, Wiederhold KH, Mistl C, Rothacher S, Ledermann B, Bürki K, Frey P, Paganetti PA, Waridel C, Calhoun ME, Jucker M, Probst A, Staufenbiel M, Sommer B (1997) Two amyloid precursor protein transgenic mouse models with Alzheimer disease-like pathology. Proc Natl Acad Sci U S A 94, 13287-13292.

[34] Shimizu E, Kawahara K, Kajizono M, Sawada M, Nakayama H (2008) IL-4-induced selective clearance of oligomeric $\beta$-amyloid peptide1-42 by rat primary type 2 microglia. J Immunol 181, 6503-6513.

[35] Ohsawa K, Imai Y, Nakajima K, Kohsaka S (1997) Generation and characterization of a microglial cell line, MG5, derived from a p53-deficient mouse. Glia 21, 285-298.

[36] Dam DV, D’Hooge R, Staufenbiel M, Ginneken CV, Meir FV, De Deyn PP (2003) Age-dependent cognitive decline in the APP23 model precedes amyloid deposition. Eur J Neurosci 17, 388-396

[37] Ishido M, Shudo K (2009) Oral administration of synthetic retinoid Am80 inhibits the development of type 1 diabetes in non-obese diabetic (NOD) mice. Biol Pharm Bull 32, 157159.

[38] Morris R (1984) Developments of a water-maze procedure for studying spatial learning in the rat. J Neurosci Methods 11, 47-60.

[39] Vorhees CV, Williams MT (2006) Morris water maze: Procedures for assessing spatial and related forms of learning and memory. Nat Protoc 1, 848-858.

[40] Iwata N, Takaki Y, Fukami S, Tsubuki S, Saido TC (2002) Region-specific reduction of A $\beta$-degrading endopeptidase, neprilysin, in mouse hippocampus upon aging. $J$ Neurosci Res 70, 493-500.
[41] Huang SM, Mouri A, Kokubo H, Nakajima R, Suemoto T, Higuchi M, Staufenbiel M, Noda Y, Yamaguchi H, Nabeshima T, Saido TC, Iwata N (2006) Neprilysin-sensitive synapseassociated amyloid- $\beta$ peptide oligomers impair neuronal plasticity and cognitive function. J Biol Chem 281, 1794117951.

[42] Chomczynski P, Sacchi N (1987) Single-step method of RNA isolation by acid guanidinium thiocyanate-phenol-chloroform extraction. Anal Biochem 162, 156-159.

[43] Mildner A, Schlevogt B, Kierdorf K, Böttcher C, Erny D, Kummer MP, Quinn M, Brück W, Bechmann I, Heneka MT, Priller J, Prinz M (2011) Distinct and non-redundant roles of microglia and myeloid subsets in mouse models of Alzheimer's disease. J Neurosci 31, 11159-11171.

[44] Yamanaka M, Ishikawa T, Griep A, Axt D, Kummer MP, Heneka MT (2012) PPAR $\gamma / \operatorname{RXR} \alpha$-induced and CD36-mediated microglial amyloid- $\beta$ phagocytosis results in cognitive improvement in amyloid precursor protein/presenilin 1 mice. $J$ Neurosci 32, 17321-17331.

[45] Tontonoz P, Nagy L, Alvarez JG, Thomazy VA, Evans RM (1998) PPAR $\gamma$ promotes monocyte/macrophage differentiation and uptake of oxidized LDL. Cell 93, 241-252.

[46] Heyman RA, Mangelsdorf DJ, Dyck JA, Stein RB, Eichele G, Evans RM, Thaller C (1992) 9-cis Retinoic acid is a high affinity ligand for the retinoid X receptor. Cell 68, 397-406.

[47] Miwako I, Kagechika H (2007) Tamibarotene. Drugs Today 43, 563-568.

[48] Solomin L, Johansson CB, Zetterström RH, Bissonnette RP, Heyman RA, Olson L, Lendahl U, Frisén J, Perlmann T (1998) Retinoid-X receptor signalling in the developing spinal cord. Nature 395, 398-402.

[49] Zhang C, Hazarika P, Ni X, Weidner DA, Duvic M (2002) Induction of apoptosis by bexarotene in cutaneous T-cell lymphoma cells: Relevance to mechanism of therapeutic action. Clin Cancer Res 8, 1234-1240.

[50] Kagechika H, Shudo K (2005) Synthetic retinoids: Recent developments concerning structure and clinical utility. J Med Chem 48, 5875-5883.

[51] Oddo S, Caccamo A, Smith IF, Green KN, LaFerla FM (2006) A dynamic relationship between intracellular and extracellular pools of A $\beta$. Am J Pathol 168, 184-194.

[52] Tomiyama T, Matsuyama S, Iso H, Umeda T, Takuma H, Ohnishi K, Ishibashi K, Teraoka R, Sakama N, Yamashita T, Nishitsuji K, Ito K, Shimada H, Lambert MP, Klein WL, Mori H (2010) A mouse model of amyloid $\beta$ oligomers: Their contribution to synaptic alteration, abnormal tau phosphorylation, glial activation, and neuronal loss in vivo. J Neurosci 30, 4845-4856.

[53] Melino G, Draoui M, Bernardini S, Bellincampi L, Reichert U, Cohen P (1996) Regulation by retinoic acid of insulindegrading enzyme and of a related endoprotease in human neuroblastoma cell lines. Cell Growth Differ 7, 787-796.

[54] Bulloj A, Leal MC, Surace EI, Zhang X, Xu H, Ledesma MD, Castaño EM, Morelli L (2008) Detergent resistant membraneassociated IDE in brain tissue and cultured cells: Relevance to A $\beta$ and insulin degradation. Mol Neurodegener 3, 22.

[55] Killick R, Scales G, Leroy K, Causevic M, Hooper C, Irvine EE, Choudhury AI, Drinkwater L, Kerr F, Al-Qassab H, Stephenson J, Yilmaz Z, Giese KP, Brion JP, Withers DJ, Lovestone S (2009) Deletion of Irs2 reduces amyloid deposition and rescues behavioural deficits in APP transgenic mice. Biochem Biophys Res Commun 386, 257-262.

[56] Zhao Z, Xiang Z, Haroutunian V, Buxbaum JD, Stetka B, Pasinetti GM (2007) Insulin degrading enzyme activity selectively decreases in the hippocampal formation of cases at 
high risk to develop Alzheimer's disease. Neurobiol Aging 28, 824-830.

[57] Qiu WQ, Walsh DM, Ye Z, Vekrellis K, Zhang J, Podlisny MB, Rosner MR, Safavi A, Hersh LB, Selkoe DJ (1998) Insulin-degrading enzyme regulates extracellular levels of amyloid $\beta$-protein by degradation. J Biol Chem 273, 3273032738.

[58] Maghsoodi B, Poon MM, Nam CI, Aoto J, Ting P, Chen L (2008) Retinoic acid regulates RAR $\alpha$-mediated control of translation in dendritic RNA granules during homeostatic synaptic plasticity. Proc Natl Acad Sci U S A 105, 1601516020.

[59] Poon MM, Chen L (2008) Retinoic acid-gated sequencespecific translational control by RAR $\alpha$. Proc Natl Acad Sci U S A 105, 20303-20308.

[60] Higuchi M, Iwata N, Matsuba Y, Takano J, Suemoto T, Maeda J, Ji B, Ono M, Staufenbiel M, Suhara T, Saido TC (2012) Mechanistic involvement of the calpain-calpastatin system in Alzheimer neuropathology. FASEB J 26, 1204-1217.

[61] Kalinin S, Richardson JC, Feinstein DL (2009) A PPAR agonist reduces amyloid burden and brain inflammation in a transgenic mouse model of Alzheimer's disease. Curr Alzheimer Res 6, 431-437.

[62] Takeda N, Manabe I, Shindo T, Iwata H, Iimuro S, Kagechika H, Shudo K, Nagai R (2006) Synthetic retinoid Am80 reduces scavenger receptor expression and atherosclerosis in mice by inhibiting IL-6. Arterioscler Thromb Vasc Biol 26, 11771183.

[63] Kawahara K, Suenobu M, Yoshida A, Koga K, Hyodo A, Ohtsuka H, Kuniyasu A, Tamamaki N, Sugimoto Y, Nakayama H (2012) Intracerebral microinjection of interleukin-4/interleukin-13 reduces $\beta$-amyloid accumulation in the ipsilateral side and improves cognitive deficits in young amyloid precursor protein 23 mice. Neuroscience 207, 243260.

[64] Fenn AM, Henry CJ, Huang Y, Dugan A, Godbout JP (2012) Lipopolysaccharide-induced interleukin (IL)- 4 receptor- $\alpha$ expression and corresponding sensitivity to the $\mathrm{M} 2$ promoting effects of IL-4 are impaired in microglia of aged mice. Brain Behav Immun 26, 766-777.

[65] Nolan Y, Maher FO, Martin DS, Clarke RM, Brady MT, Bolton AE, Mills KH, Lynch MA (2005) Role of interleukin4 in regulation of age-related inflammatory changes in the hippocampus. J Biol Chem 280, 9354-9362.

[66] Zhu B, Buttrick T, Bassil R, Zhu C, Olah M, Wu C, Xiao S, Orent W, Elyaman W, Khoury SJ (2013) IL-4 and retinoic acid synergistically induce regulatory dendritic cells expressing Aldh1a2. J Immunol 191, 3139-3151.

[67] Carpentier A, Balitrand N, Rochette-Egly C, Shroot B, Degos L, Chomienne C (1997) Distinct sensitivity of neuroblastoma cells for retinoid receptor agonists: Evidence for functional receptor heterodimers. Oncogene 15, 1805-1813.

[68] Leroy P, Nakshatri H, Chambon P (1991) Mouse retinoic acid receptor $\alpha 2$ isoform is transcribed from a promoter that contains a retinoic acid response element. Proc Natl Acad Sci U S A 88, 10138-10142.

[69] Stellwagen D, Malenka RC (2006) Synaptic scaling mediated by glial TNF- $\alpha$. Nature 440, 1054-1059.

[70] Chang EH, Savage MJ, Flood DG, Thomas JM, Levy RB, Mahadomrongkul V, Shirao T, Aoki C, Huerta PT (2006) AMPA receptor downscaling at the onset of Alzheimer's disease pathology in double knockin mice. Proc Natl Acad Sci U S A 103, 3410-3415.

[71] Montgomery SL, Mastrangelo MA, Habib D, Narrow WC, Knowlden SA, Wright TW, Bowers WJ (2011) Ablation of TNF-RI/RII expression in Alzheimer's disease mice leads to an unexpected enhancement of pathology: Implications for chronic pan-TNF- $\alpha$ suppressive therapeutic strategies in the brain. Am J Pathol 179, 2053-2070.

[72] Dheen ST, Jun Y, Yan Z, Tay SS, Ling EA (2005) Retinoic acid inhibits expression of TNF- $\alpha$ and iNOS in activated rat microglia. Glia 50, 21-31.

[73] Hellmann-Regen J, Kronenberg G, Uhlemann R, Freyer D, Endres M, Gertz K (2013) Accelerated degradation of retinoic acid by activated microglia. J Neuroimmunol 256, 1-6.

[74] Santello M, Volterra A (2012) TNFo in synaptic function: Switching gears. Trends Neurosci 35, 638-647.

[75] Hickman SE, Allison EK, El Khoury J (2008) Microglial dysfunction and defective beta-amyloid clearance pathways in aging Alzheimer's disease mice. J Neurosci 28, 8354-8360.

[76] Mizojiri K, Okabe H, Sugeno K, Esumi Y, Takaichi M, Miyake T, Seki H, Inaba A (1997) Studies on the metabolism and disposition of the new retinoid 4-[(5,6,7,8-tetrahydro5,5,8,8-tetramethyl-2-naphthyl)carbamoyl] benzoic acid. 1st communication: Absorption, distribution, metabolism and excretion after topical application and subcutaneous administration in rats. Arzneimittelforschung 47, 59-69.

[77] Liu X, Zhang Z, Jiang Y, Hu Y, Wang Z, Liu J, Feng R, Zhang J, Huang G (2014) Novel PEG-grafted nanostructured lipid carrier for systematic delivery of a poorly soluble anti-leukemia agent Tamibarotene: Characterization and evaluation. Drug Deliv, doi:10.3109/10717544.2014.885614 